\title{
Inventory of heavy metal content in organic waste applied as fertilizer in agriculture: evaluating the risk of transfer into the food chain
}

Carla Lopes, Marta Herva, Amaya Franco-Uría, Enrique Roca

\author{
C. Lopes, M. Herva, A. Franco-Uría, E. Roca (*)
}

Sustainable Processes and Products Engineering and Management Group, Department of Chemical Engineering, School of Engineering, University of Santiago de Compostela, Campus Vida, 15782, Santiago de Compostela, Spain, e-mail: enrique.roca@usc.es

\section{A. Franco-Uría}

Process Engineering Group, Marine Research Institute IIM-CSIC, Eduardo Cabello, 6, 36208, Vigo, Spain

\begin{abstract}
Background, aim, and scope In this work, an environmental risk assessment of reusing organic waste of differing origins and raw materials as agricultural fertilizers was carried out. An inventory of the heavy metal content in different organic wastes (i.e., compost, sludge, or manure) from more than 80 studies at different locations worldwide is presented.

Materials and methods The risk analysis was developed by considering the heavy metal (primarily Cd, $\mathrm{Cu}, \mathrm{Ni}, \mathrm{Pb}$, and $\mathrm{Zn}$ ) concentrations in different organic residues to assess their potential environmental accumulation and biotransfer to the food chain and humans. A multi-compartment model was used to estimate the fate and distribution of metals in different environmental compartments, and a multipathway model was used to predict human exposure.
\end{abstract}

Results The obtained hazard index for each waste was concerning in many cases, especially in the sludge samples that yielded an average value of 0.64 . Among the metals, $\mathrm{Zn}$ was the main contributor to total risk in all organic wastes due to its high concentration in the residues and high biotransfer potential. Other more toxic metals, like $\mathrm{Cd}$ or $\mathrm{Pb}$, represented a negligible contribution.

Conclusions These results suggest that the $\mathrm{Zn}$ content in organic waste should be reduced or more heavily regulated to guarantee the safe management and reuse of waste residues according to the current policies promoted by the European Union. 
Keywords Risk assessment . Organic waste inventory . Heavy metals . Biotransfer

\section{Introduction}

Reusing organic waste as a soil fertilizer offers a number of advantages over other management alternatives because it reduces the use of other fertilizers and eliminates the necessity of its subsequent treatment or disposal (Bruun et al. 2006; Hargreaves et al. 2008). Sewage sludge and manure are the most common organic wastes applied either raw or composted (i.e., humification of the organic matter under controlled conditions). The application of such wastes to soil provides nutrients, increases organic matter, improves soil structure, and enhances nutrient absorption by plants (Weber et al. 2007; Singh and Agrawal 2008). Therefore, the use of different types of organic waste in agriculture or farming activities instead of using conventional chemical fertilizers should be preferred in terms of sustainability. These residues can also be used as amendments to regenerate infertile soils and for improving plant cover (Soliva and Paulet 2001).

However, the European legislation has become more restrictive on the content of priority pollutants in residues that are used as raw materials for the production of fertilizers or as fertilizers themselves (European Commission 2004), ultimately limiting waste reuse in agriculture. Currently, there are several types of organic waste and compost, classified according to the origin of its raw materials (European Community 2006): urban residues, agricultural and forest residues, wastewater treatment sludge, residues resulting from terrestrial remediation activities, residues from industrial processes, and mixtures of these. Depending on the raw material, toxicity due to the presence of persistent organic pollutants or heavy metals may become important (Hua et al. 2008; Oleszczuk 2008). The application of organic waste (i.e., compost, sludge or manure) to land, especially agricultural crops, represents a significant input of nutrients (i.e., nitrogen, sulfur, and phosphorus), but also of metals, some of them being toxic like cadmium or lead (Pichtel and Anderson 1997; Pinamonti et al. 1997; Lipoth and Schoenau 2007; Madridet al. 2007). Thus, organic waste likely to be used as fertilizer must contain metal levels that are suitable for soil application in accordance with Directive 86/278/EEC (European Community 1986), which regulates the use of sewage sludge in agriculture. However, pollutant concentration should be considered a unique criterion for waste reuse. Repeated application over extended periods of time and an increase in application frequency favor metal accumulation and biotransfer. Depending on soil composition and the presence of metals in the reused waste, specific chemical and physical associations can cause the accumulation of these pollutants in soil. This soil build-up might cause severe adverse 
effects to animal and human health through their incorporation into the food chain, with the intake of food grown in contaminated areas as the most direct route of exposure (Lăcătuşuet al. 1996; Khan etal. 2008; Sridhara Cari et al. 2008; Smith et al. 2009;Zhuang et al. 2009). Environmental risk assessment (ERA) could assist in establishing safety conditions for organic waste application as fertilizer to agricultural crops and pasture production (Franco et al. 2006). In this type of analysis, it is important to consider the proper mechanisms of transfer, accumulation, and exposure for a reliable estimation of human exposure to heavy metals, according to the waste-reuse scenario under consideration.

There are numerous research studies related to the metal contents of different types of organic waste, such as manure (Bolan et al. 2004) and compost (Ciavatta et al. 1993; Ayuso et al. 1996; Ihnat and Fernandes 1996; Goi et al. 2006; Cai et al. 2007; Chen et al. 2008; Farrell and Jones 2009a; Haroun et al. 2009), and the potential biotransfer to soil and crops (Pinamonti et al. 1997; Bazzoffi et al. 1998; Cole et al. 2001; Korboulewsky et al. 2002; Casado-vela et al. 2007; Kidd et al. 2007; Bose and Bhattacharyya 2008; Odlare et al. 2008; Achiba et al. 2009). Many of these authors have stressed both the consequences of the presence of metals for both humans and the environment and the need for controlled agricultural activities.

In this work, a wide inventory of the heavy metal content of different types of organic waste was taken. Data collected in the inventory was used to estimate the possible risk derived from the reuse and application of these residues as fertilizers in agriculture. A multi-compartment fate and exposure model was used. This was the basis of a decision support tool for organic waste management (Río et al. 2011), to evaluate the transfer of heavy metals into the food chain and the possible impacts on human health. The influence of model parameterization on the results obtained was assessed by developing a sensitivity analysis to evaluate the contribution of the different variables considered in the model to uncertainty, especially those related to soil properties. The information and results provided in this work are intended to contribute to the current body of knowledge on the reuse of different types of organic waste as fertilizers within the field of environmental management and safety.

\section{Materials and methods}

\subsection{Data inventory}

An exhaustive review of studies presenting the heavy metal content of organic waste was collected from the scientific literature. The resulting inventory included 194 cases of different types of residues, which 
were classified into three main categories: compost (83 cases, Table 1), sludge and other uncomposted wastes (81 cases, Table 2), and manure (30 cases, Table 3). The inventory focused on residues of domestic origin, assuming a final fate of reuse in agriculture. Special attention was paid to works developed during the last decade, although previous studies were also considered. A higher number of studies involving compost or sludge were considered since, in general, reusing this residue might be more problematic due to its higher metal content compared to other types of organic waste. More cases were included in the inventory to better reflect the effect of possible variations in metal concentration among different sludges (domestic and industrial origin). Even though some studies presented data on several metals, only the five most commonly analyzed (i.e., $\mathrm{Cd}, \mathrm{Cu}, \mathrm{Ni}, \mathrm{Pb}$, and $\mathrm{Zn}$ ) were considered in the inventory for calculating risk indexes. Another criterion for selecting these metals was to reflect different levels of toxicity in the inventory: high ( $\mathrm{Cd}$ and $\mathrm{Pb})$, mid ( $\mathrm{Ni})$, and low ( $\mathrm{Cu}$ and $\mathrm{Zn})$.

\subsection{Environmental risk assessment model}

An ERA was used to estimate the potential adverse effects on human health resulting from the application of organic waste containing heavy metals as fertilizer in the production of forage. The importance of the different metals' distribution mechanisms in the environment varies depending on soil characteristics (e.g., pH, organic matter, and texture), climatic conditions (e.g., rainfall), and agricultural practices (e.g., intensity and frequency).

The accumulation of heavy metals in soil was assessed by establishing a dynamic mass balance between input and output fluxes according to Boekhold and van der Zee (1991) and Moolenaar et al. (1997). The input of metals to the agricultural soil surface may have several contributors: addition of organic waste (i.e., sewage sludge, manure, or compost), irrigation with wastewater, application of commercial fertilizers, or atmospheric deposition. Considering the scope of this work, only the application of organic waste was considered as an input to the model. Output fluxes from soil included leaching from plough to deeper soil layers by precipitation and plant uptake. Data corresponded to areas with different soil types/characteristics, climatology, and precipitation rates. Since metal concentration in solution is usually correlated with soil properties (e. g., $\mathrm{pH}$, metal soil concentration, metal transfer by soil erosion, organic matter, cation exchange capacity, and fulvic and humic acid concentration) and climatology characteristics (e.g., precipitation rate), the leaching of heavy metals into groundwater may be more important in some areas than in others (Sauvé et al. 1997, 2000; Krishnamurti and Naidu 2002; Keller and Schulin 2003; Carlon et al. 2004). Plant absorption rate is related to metal concentration in solution and, therefore, is also dependent on soil type. With the aim of analyzing the effect of organic waste 
metal content on total risk regardless of soil location, the parameterization of the fate model (i.e., initial soil concentrations, waste application rates, and soil characteristics) was the same for all cases included in the inventory (Table 4). This criterion was also adopted due to the lack of data for these parameters in the majority $(>60 \%)$ of studies.

Human exposure was estimated by taking into account five exposure pathways according to the scenario evaluated: (1) intake of meat from cattle grazing in the area, (2) ingestion of milk from cattle grazing in the area, (3) dermal absorption from soil, (4) ingestion of soil, and (5) inhalation of resuspended soil particles. Some of the exposure routes were selected based on the primary activities of the population inhabiting in the study area (e.g., farming). Minor contributions from pathways with a soil exposure source were also expected.

Cattle are exposed to metals through ingestion of contaminated food (i.e., soil, vegetation, and water), by inhalation of resuspended soil particles, or by absorption through the skin. However, only the ingestion pathways were considered to evaluate cattle exposure because dermal contact and inhalation are generally not as significant (ORNL 2004). The equations and empirical multicorrelation models used to estimate metal concentrations in solution (Sauvé et al. 2000), plants (Efroymson et al. 2001), and soil can be found in a previous work (Franco et al. 2006), as along with the exposure model equations and their parameterization.

Quantification of the potential non-carcinogenic risk was determined by a hazard quotient (HQ), which was calculated by dividing the individual doses (milligrams contaminant per kilogram of body weight per day) of each metal by the corresponding reference dose (RfD, milligrams contaminant per kilogram of body weight per day) as shown in Eq. 1.

$$
H Q=\frac{\text { Individual dose }}{R f D}
$$

Route-to-route extrapolations were needed when no specific dose-response data were available (IRIS database, US EPA 2010). A hazard index (HI) was obtained for each case in the inventory by aggregating the HQs corresponding different metals contained in each of the organic considered, reflecting the global risk (Eq. 2).

$$
\mathrm{HI}=\sum \mathrm{HQ}_{\text {metal }}
$$


A HI higher than 1.0 indicates that adverse human health effects are expected to occur.

\subsection{Sensitivity analysis}

A Monte Carlo simulation of 10,000 iterations was developed using the commercial software, Crystal Ball, Version 7 (Decisioneering). This numerical technique propagates parameter uncertainty through the model equations. In this particular case, the sensitivity analysis was only performed on the fate model's parameters to evaluate the influence that different locations with different soil characteristics and climatology might have on both the HQ and HI. Probability distributions with a standard deviation of $50 \%$ around the nominal value were assigned to average production, soil organic matter, and soil infiltration (Table 4). A standard deviation of 100\% was assigned to the precipitation rate to observe the effect of precipitation absence in arid locations. Finally, soil $\mathrm{pH}$ was allowed to vary between 5.0 and 7.5 .

\section{Results and discussion}

\subsection{Risk indexes}

The data compiled on heavy metals content in compost, sludge, and manure are shown in Tables 1, 2, and 3 (inventory tables), respectively. It can be seen that sludge contained the highest values of average heavy metal concentration, 50-90\% higher than in compost (depending on the metal) and considerably higher than in manure (almost 20 times higher for toxic metals like $\mathrm{Cd}$ or $\mathrm{Pb}$ ). Sludge composition primarily depends on the origin of the effluent treated in the biological reactor. Metal concentrations of concern are typically found in sludge (or compost) coming from a wastewater treatment plant that collects industrial effluents (Soliva and Paulet 2001; Bose and Bhattacharyya 2008), although high concentrations can also be found in domestic sewage depending on the country of origin (Kandpal et al. 2004; Chen et al. 2008; Hua et al. 2008; Egiarte et al. 2009; Lasheen and Ammar 2009).

In general, our metal content values in sludge are within the ranges of those compiled in other works (Pathak et al. 2009). More specifically, average contents of $\mathrm{Cu}, \mathrm{Pb}$, and $\mathrm{Zn}$ in Table 2 agreed well with sludge values proposed by the EU, while mean values for $\mathrm{Ni}$ and $\mathrm{Cd}$ were in accordance with those reported by the USA (Stylianou et al. 2008). In Table 2, it should be highlighted that other uncomposted wastes like municipal solid waste or green waste were considered in addition to sludge. Although composting can effectively reduce the availability of metals (García et al. 1995; Smith 2009), it has 
proved difficult to significantly reduce the total metal content of the initial residue (Manios et al. 2003; Nomeda et al. 2008; Oleszczuk 2008). In fact, this content can be even higher in compost than in the initial waste for certain metals due to the weight loss suffered through mineralization (García et al. 1995). Intermediate metal levels between sludge and manure can be found in compost because composted waste can be either sludge or manure.

On the other hand, the presence of metals in manure is due to animal (e.g., cattle, pig, and poultry) excretion of trace elements contained in their diet or other health supplements (Petersen et al. 2007; European Commission (2003)). Thus, the concentration of metals in manure is generally moderate, especially for toxic $\mathrm{Cd}$ and $\mathrm{Pb}$. Micronutrients like $\mathrm{Cu}$ and $\mathrm{Zn}$ can reach substantial levels because the animal is usually overdosed with these oligoelements to increase productivity and disease resistance (Nicholson et al. 1999).

The metal HQ and HI were calculated for each of the 194 cases in the inventory tables using the multicompartment risk assessment model described in the previous section. It can be seen in Tables 1, 2, and 3 that the HI value exceeded the recommended ERA safety limit of 1.0 in 14\% of sludge cases, with an average value of 0.64 . The percentage of cases above 1.0 was lower for compost (4\%), with an average value 0.42 . However, it is important to note that the risk estimated is incremental in that it only reflects one of the possible routes of metal exposure for humans, and the obtained HI values for sludge and compost become of greater concern within this context despite being lower than 1.0 in most cases. Regarding manure, its reuse as agricultural fertilizer could be considered a safer practice $(0.25$ average HI). Note that only total metal contents in waste were used to calculate HQs and the HI, and aspects like bioavailability were not assessed in this work. This fact could reduce the final value of the HI because some metals may be strongly complexed with organic matter (García et al. 1995; Zheng et al. 2004; Nomeda et al. 2008). Hence, it is possible that taking bioavailability into account would result in the reduction of the HI for organic wastes. However, metal bioavailability depends not only on metal content, but also on the chemical properties of organic waste (Smith 2009).

Average metal-specific HQs and an average HI were calculated for each type of waste (Fig. 1). The highest contribution to the HI was the essential trace element $\mathrm{Zn}$, and typical toxic elements like $\mathrm{Cd}$ and $\mathrm{Pb}$ posed a minor contribution to total risk. Although a very low dose (RfD) of these metals can result in severe adverse effects to human health, it is necessary to take into account each evaluated case. From the original organic waste applied on land, metals have to be transferred to vegetation and cattle, then to humans. Thus, the biotransfer potential, rather than the toxicity potential, would be the best indicator of 
the magnitude of risk in this particular scenario. According to the Risk Assessment Information System (ORNL 2010), biotransfer factors (BTFs) to meat and milk for $\mathrm{Cd}, \mathrm{Cu}$, and $\mathrm{Pb}$ ranged between $1 \cdot 10^{-03}$ and $1 \cdot 10^{-04}$ in magnitude, while for $\mathrm{Zn}$, the values were $1 \cdot 10^{-01}$, and $1 \cdot 10^{-02}$ for meat and milk, respectively. Thus, although the ingestion RfDs of $\mathrm{Zn}$ was significantly higher in comparison with the other metals (i.e., the dose a human ingests must be high to produce any adverse effect on health), significant concentrations of $\mathrm{Zn}$ in either type of organic waste and high BTFs resulted in large HQs, exceeding the safety limit for several cases of compost and sludge. Ni also contributed significantly to the HI because of its high BTF to milk $\left(1.6 \cdot 10^{-01}\right)$. An analysis of the exposure pathways considered in the scenario revealed that ingestion of meat, followed by milk ingestion, represented between $75 \%$ and $90 \%$ of the total risk on average in all cases inventoried. As expected, pathways involving direct absorption from soil contact and inhalation had a minor effect on the risk index, and both the $\mathrm{Cd}$ and $\mathrm{Pb}$ HQ were low.

The HQs of metals for each type of organic waste were proportional to their concentration. The contribution of $\mathrm{Ni}$ to the $\mathrm{HI}$ was approximately $10-12 \%$ for compost and sludge and $6 \%$ in manure. In the case of $\mathrm{Zn}$, the opposite trend occurred, with a contribution to manure of $68 \%$ and to compost and sludge of $64 \%$. So, although some authors have indicated that levels of $\mathrm{Zn}$ in manure are generally lower than in other types of organic waste (Soliva and Paulet 2001; Achiba et al. 2009), we found similar levels in manure, compost, and sludge for the cases included in the inventory. Together with $\mathrm{Cu}, \mathrm{Zn}$ content was higher than that of other metals in manure due to excretion of these oligoelements after supplementation in cattle. Zn concentration was also highest in compost and sludge, but a more significant presence of the other metals was also found, especially for the toxic $\mathrm{Cd}$ and $\mathrm{Pb}$. The average level of $\mathrm{Zn}$ in sludge calculated from the studies in the inventory was $1,200 \mathrm{mg} \cdot \mathrm{kg}^{-1}$, while in manure it was $300 \mathrm{mg} \cdot \mathrm{kg}^{-1}$.

$\mathrm{Zn}$ can end up in wastewater and sludge from several different sources: excretion by humans from ingested food or water, use of galvanized materials, car emissions, car washes, metallurgy, mining, painting, and any applications that involve high levels of $\mathrm{Zn}$ in domestic and industrial wastewaters (Sörme and Lagerkvist 2002). Zn is an essential element for humans, with a recommended dietary intake of approximately $0.16 \mathrm{mg} \cdot \mathrm{kg}^{-1} \cdot \mathrm{day}^{-1}$ for men and $0.13 \mathrm{mg} \mathrm{kg}^{-1} \mathrm{day}^{-1}$ for women (ATSDR (Agency for Toxic Substances and Disease Registry) 2005). However, prolonged oral exposure to zinc at high levels ( 2 $\mathrm{mg} \mathrm{kg}^{-1}$ day $^{-1} \mathrm{Zn}$ ) may cause severe symptoms of copper deficiency, including anemia and neutropenia (Ramadurai et al. 1993). 


\subsection{Legislative limits}

Proposed limits for heavy metals in organic soil fertilizer amendments are given in Table 5, and HIs for each specified use class (A, B, and C) have been calculated. Considering metal content, class A was the most appropriate for cultivating crops intended for direct human consumption. The resulting HI after 100 years of applications of this type of organic waste was 0.23 , but a low percentage of compost (20\%) and sludge $(10 \%)$ considered in the inventory can be classified within this category. This percentage increased to $45 \%$ of cases adequate to be applied according to class A guidelines in manure. Sixty percent of compost and $40 \%$ of sludge fell into the type B classification, which is more adequate to fertilize land for forage or fruit production. Finally, despite its higher metal content, fertilizers classified under type $\mathrm{C}$ had HQs and a global HI that were similar to type B because of its limited application rate, which must be lower than $5 \mathrm{t}^{-1} \mathrm{y}^{-1}$.

In general, countries presented similar values of maximum permissible contents in compost for each metal, providing, an acceptable $\mathrm{HI}$ as a first approximation. However, different soil properties and climate could influence the final value of the risk index, which was evaluated with a sensitivity analysis. Finally, although legislation allows the use of sludge containing much higher concentrations of heavy metals (Goi et al. 2006; Stylianou et al. 2008), its application in agriculture is usually strongly constrained to low application rates and frequencies, as well as to specific times of the year. These restrictions were not considered in the estimation of sludge HI, although they could result in a decrease of metal risk indexes. Despite this worstcase scenario, incremental risk cannot be considered negligible, and metal limits in organic waste should be decreased, as stated previously in literature (Madrid et al. 2007).

\subsection{Sensitivity analysis}

Figure 2 illustrates the influence of soil properties and climate in the HQ of each metal and in the total HI. Soil pH played a key role in the magnitude of total risk for $\mathrm{Cd}, \mathrm{Ni}$, and $\mathrm{Zn}$ because an increase in the value of this parameter provoked a significant reduction in HQ and HI. Low pH values enhance metal solubility, mobility, and bioavailability in soil (Smith 1994; Planquart et al. 1999), as reflected in certain countries' legislation that establishes a different organic waste application rate depending on the $\mathrm{pH}$ value (i.e., lower or higher than 7). 
Soil organic matter only influenced the HQ of $\mathrm{Pb}$ significantly (70.9\% of variance). It had a lower effect on $\mathrm{Cd}$ and $\mathrm{Ni}$ and was negligible for $\mathrm{Cu}$ and $\mathrm{Zn}$. Figure 2 shows that an increase in soil organic matter resulted in an increase in the $\mathrm{Pb}$ HQ (i.e., positive effect). $\mathrm{Pb}$ is one of the most strongly adsorbed metals by organic matter and, thus, may be effectively retained and accumulated in the soil matrix (Schroth et al. 2008). Lead's low biotransfer potential implies that the direct soil exposure pathways contributed more to its HQ. Organic matter can fix and increase the Pb concentration in soil and increase its HQ accordingly, although this value was very low compared with the total HI. Therefore, the influence of organic matter could be significant in scenarios where direct and prolonged contact with $\mathrm{Pb}$ contaminated soil is expected.

Finally, the HQ of $\mathrm{Cu}$ was primarily affected by climatic conditions (i.e., precipitation rate) and was less sensitive to $\mathrm{pH}$ changes (Smith 1994). In contrast to the behavior of the other metals, an increase in precipitation would result in a decrease in risk due to $\mathrm{Cu}$ according to the sensitivity analysis. Enhanced leaching of $\mathrm{Cu}$ through the soil matrix (Kidd et al. 2007) escapes metal biotransfer from soil solution to vegetation and cattle, and subsequently to humans, leading to a low HQ.

The high influence of $\mathrm{pH}$ on the global HI can also be seen in Fig. 2. This influence is due to the high contribution of $\mathrm{Zn}$, followed by $\mathrm{Ni}$, because both metals significantly depend on $\mathrm{pH}$. Precipitation rate is the second most influential variable at $20 \%$, due to the contribution of $\mathrm{Cu}$ (after $\mathrm{Zn}$ and Ni). Thus, soil and climate properties (i.e., location) can significantly vary the magnitude of risk depending on the metal. For example, the sensitivity analysis revealed that in the case of organic waste reuse, locations with acidic soils and high precipitation rates would be more affected by $\mathrm{Zn}$ exposure. These two scenarios can be found within the same country, Spain, where the Mediterranean area has basic soils and low precipitation rates, but the Atlantic area (NW) has acidic soils and high precipitation rates.

\section{Conclusions}

In this study, a wide inventory of the heavy metal content in three types of organic wastes (i.e., compost, sludge, and manure) was taken. Health risks due to the reuse of these residues as agricultural fertilizers were determined by an ERA. The results indicated that sludge contained the highest concentrations of metals, and the presence of toxic metals like $\mathrm{Cd}$ and $\mathrm{Pb}$ was more significant than in compost and manure. As expected, sludge reuse in the proposed scenario resulted in the highest incremental risk. Surprisingly, the metal with the greatest risk contribution to the three types of organic waste was $\mathrm{Zn}$, making the presence of toxic $\mathrm{Cd}$ and $\mathrm{Pb}$ almost negligible in terms of risk. Although $\mathrm{Zn}$ presents a very 
low level of toxicity as an essential element to life, its high biotransfer potential may create in significant concentrations that exceed the recommended doses in organic matrices like plants, cattle, and humans. Therefore, specific measures should be taken to regulate the $\mathrm{Zn}$ content of organic waste depending on its final management solution. The origin of the $\mathrm{Zn}$ should also be established for proper reduction measurements in emissions, especially in sludge. However, a worst-case scenario approach was selected, and the risk may be overestimated because legislation restrictions on the application of sludge were not considered. Another key aspect, bioavailability, was not addressed in the present work. Future efforts should be focused on assessing metal speciation in the soil solution, either as inorganic complexes or bound to humic and fulvic acids.

Acknowledgments This work was supported by the Spanish Government (Science and Innovation Ministry) through the Project INDIE (CTM2010-18893). Marta Herva wishes to thank the University of Santiago de Compostela for her pre-doctoral contract. Dr. Amaya Franco-Uría would like to thank MICINN for the support provided by the "Juan de la Cierva" Subprogram.

\section{References}

Achiba WB, Gabteni N, Lakhdar A, Du Laing G, Verloo M, Jedidi N, Gallali T (2009) Effects of 5-year application of municipal solid waste compost on the distribution and mobility of heavy metals in a Tunisian calcareous soil. Agric Ecosyst Environ 130:156-163

Acosta Y, Paolini J, Flores S, Benzo Z, El Zauahre M, Toyo L, Señor A (2003) Evaluation of heavy metals in three organic wastes of different nature. Multiciencias 3:1-16 (in Spanish)

Ahlberg G, Gustafsson O, Wedel P (2006) Leaching of metals from sewage sludge during one year and their relationship to particle size. Environ Pollut 144:545-553

Alvarenga P, Gonçalves AP, Fernandes RM, de Varennes A, Vallini G, Duarte E, Cunha-Queda AC (2008) Evaluation of composts and liming materials in the phytostabilization of a mine soil using perennial ryegrass. Sci Total Environ 406:43-56

ATSDR (Agency for Toxic Substances and Disease Registry) (2005) Toxicological profile for Zn. Available at: http://www.atsdr.cdc. gov/toxprofiles/tp60.html. Accessed 27 January 2010

Ayuso M, Hernández T, García C, Pascual JA (1996) Biochemical and chemical-structural characterization of different organic materials used as manures. Bioresour Technol 57:201-207

Baldwin KR, Shelton JE (1999) Availability of heavy metals in compost-amended soil. Bioresour Technol 69:1-14

Bazzoffi P, Pellegrini S, Rocchini A, Morandi M, Grasselli O (1998) The effect of urban refuse compost 
and different tractors tyres on soil physical properties, soil erosion and maize yield. Soil Tillage Res 48:275-286

Boekhold AE, Van Der Zee SEATM (1991) Long term effects of soil heterogeneity on cadmium behaviour in soil. J Contam Hydrol 17:371-390

Bolan NS, Adriano DC, Mahimairaja S (2004) Distribution and bioavailability of trace elements in livestock and poultry manure by-products. Crit Rev Environ Sci Technol 34:291-338

Bose S, Bhattacharyya AK (2008) Heavy metal accumulation in wheat plant grown in soil amended with industrial sludge. Chemosphere 70:1264-1272

Bruun S, Hansen TL, Christensen TH, Magid J, Jensena LS (2006) Application of processed organic municipal solid waste on agricultural land — a scenario analysis. Environ Model Assess 11:251-265

Businelli D, Massaccesi L, Said-Pullicino D, Gigliotti G (2009) Longterm distribution, mobility and plant availability of compostderived heavy metals in a landfill covering soil. Sci Total Environ 407:1426-1435

Cai Q-Y, Mob C-H, Wu Q-T, Zeng Q-Y, Katsoyiannis A (2007) Concentration and speciation of heavy metals in six different sewage sludge-composts. J Hazard Mater 147:1063-1072

Carlon C, Dalla Valle M, Marcomini A (2004) Regression models to predict water-soil heavy metals partition coefficients in risk assessment studies. Environ Pollut 127:109-115

Casado-Vela J, Sellés S, Díaz-Crespo C, Navarro-Pedreño J, Mataix-Beneyto J, Gómez I (2007) Effect of composted sewage sludge application to soil on sweet pepper crop (Capsicum annuum var. annuum) grown under two exploitation regimes. Waste Manage 27:1509-1518

Charest M-H, Beauchamp CJ (2002) Composting of de-inking paper sludge with poultry manure at three nitrogen levels using mechanical turning: behaviour of physico-chemical parameters. Bioresour Technol 81:7-17

Chen M, Li X-M, Yang Q, Zeng G-M, Zhang Y, Liao D-X, Liu J-J, Hu JM, Guo L (2008) Total concentrations and speciation of heavy metals in municipal sludge from Changsha, Zhuzhou and Xiangtan in middle-south region of China. J Hazard Mater 160:324-329

Cherif H, Ayari F, Ouzari H, Marzorati M, Brusetti L, Jedidi N, Hassen A, Daffonchio D (2009) Effects of municipal solid waste compost, farmyard manure and chemical fertilizers on wheat growth, soil composition and soil bacterial characteristics under Tunisian arid climate. Eur J Soil Biol 45:138145

Chicón Reina L (2003) Speciation of heavy metals in municipal sewage sludge and application of sewage sludge to improve soil conditions. Spin Cero 7:101-106 (in Spanish)

Ciavatta C, Govi M, Simoni A, Sequi E (1993) Evaluation of heavy metals during stabilization of organic matter in compost produced with municipal solid wastes. Bioresour Technol 43:147-153 
Clemente R, Paredes C, Bernal MP (2007) A field experiment investigating the effects of olive husk and cow manure on heavy metal availability in a contaminated calcareous soil from Murcia (Spain). Agric Ecosyst Environ 118:319-326

Cole LJ, McCracken DI, Foster GN, Aitken MN (2001) Using Collembola to assess the risks of applying metal-rich sewage sludge to agricultural land in western Scotland. Agric Ecosyst Environ 83:177189

Efroymson RA, Sample BE, Suter GW II (2001) Uptake of inorganic chemicals from soil by plant leaves: regressions of field data. Environ Toxicol Chem 20:2561-2571

Egiarte G, Corti G, Pinto M, Arostegui J, Macías F, Ruíz-Romero E, Camps Arbestain M (2009) Fractionation of $\mathrm{Cu}, \mathrm{Pb}, \mathrm{Cr}$, and $\mathrm{Zn}$ in a soil column amended with an anaerobic municipal sewage sludge. Water Air Soil Pollut 198:133-148

European Commission (2003) Commission Regulation (EC) no. 1334/ 2003 of 25 July 2003 amending the conditions for authorisation of a number of additives in feedingstuffs belonging to the group of trace elements. Off J Eur Comm L187:11

European Commission (2004) Final report on heavy metals and organic compounds from wastes used as organic fertilisers, ENV. A.2./ETU/2001/0024, July 2004

European Community (1986) Council Directive of 12 June 1986 on the protection of the environment, and in particular of the soil, when sewage sludge is used in agriculture (86/278/EEC). Off J Eur Comm L181:6-12

European Community (2006) Directive 2006/12/EC of the European Parliament and of the Council of 5 April 2006 on waste. Off J Eur Union L114:9-21

Fang M, Wong JWC (1999) Effects of lime amendment on availability of heavy metals and maturation in sewage sludge composting. Environ Pollut 106:83-89

Farrell M, Jones DL (2009a) Critical evaluation of municipal solid waste composting and potential compost markets. Bioresour Technol 100:4301-4310

Farrell M, Jones DL (2009b) Heavy metal contamination of a mixed waste compost: metal speciation and fate. Bioresour Technol 100:4423-4432

Franco A, Schuhmacher M, Roca E, Domingo JL (2006) Application of cattle manure as fertilizer in pastures: the estimate of increased risk due to the accumulation of metals using a multicompartment model. Environ Int 32:724-732

Fuentes A, Lloréns M, Sáez J, Aguilar MI, Ortuño JF, Meseguer VF (2004) Phytotoxicity and heavy metals speciation of stabilised sewage sludges. J Hazard Mater 108:161-169

Fuentes D, Valdecantos A, Cortina J, Vallejo VR (2007) Seedling performance in sewage sludgeamended degraded mediterranean woodlands. Ecol Eng 31:281-291 
García C, Moreno JL, Hernández T, Costa F, Polo A (1995) Effect of composting on sewage sludges contaminated with heavy metals. Bioresour Technol 53:13-19

García H, El Zauahre M, Morán H, Acosta Y, Senior A, Fernández N (2006) Comparative analysis of two digestion techniques for the determination of heavy metals in sewage sludge. Multiciencias 6:234-243 (in Spanish)

García-Gil JC, Plaza C, Soler-Rovira P, Polo A (2000) Long-term effects of municipal solid waste compost application on soil enzyme activities and microbial biomass. Soil Biol Biochem 32:19071913

Goi D, Tubaro F, Dolcetti G (2006) Analysis of metals and EOX in sludge from municipal wastewater treatment plants: a case study. Waste Manage 26:167-175

Greenway GM, Song QJ (2002) Heavy metal speciation in the composting process. J Environ Monit 4:300-305

Hachicha S, Sellami F, Cegarra J, Hachicha R, Drira N, Medhioub K, Ammar E (2009) Biological activity during co-composting of sludge issued from the OMW evaporation ponds with poultry manure-physico-chemical characterization of the processed organic matter. J Hazard Mater 162:402-409

Hackett GAR, Easton CA, Duff SJB (1999) Composting of pulp and paper mill fly ash with wastewater treatment sludge. Bioresour Technol 70:217-224

Hargreaves JC, Adl MS, Warman PR (2008) A review of the use of composted municipal solid waste in agriculture. Agric Ecosyst Environ 123:1-14

Haroun M, Idri A, Omar S (2009) Analysis of heavy metals during composting of the tannery sludge using physicochemical and spectroscopic techniques. J Hazard Mater 165:111-119

Hua L, Wu W-X, Liu Y-X, Tientchen CM, Chen Y-X (2008) Heavy Metals and PAHs in sewage sludge from twelve wastewater treatment plants in Zhejiang province. Biomed Environ Sci 21:345-352

Hyun H, Chang AC, Parker DR, Page AL (1998) Cadmium solubility and phytoavailability in sludgetreated soil: effects of soil organic matter. J Environ Qual 27:329-334

Ihnat M, Fernandes L (1996) Trace element characterization of composted poultry manure. Bioresour Technol 57:143-156

Illera V, Walter I, Cala V (2001) Heavy metals levels in Thymus zygis developed in amended soils with urban organic wastes. Rev Int Contam Ambient 17:179-186 (in Spanish)

Jordan SN, Mullen GJ, Murphy MC (2008) Composition variability of spent mushroom compost in Ireland. Bioresour Technol 99:411-418

Kandpal G, Ram B, Srivastava PC, Singh SK (2004) Effect of metal spiking on different chemical pools and chemically extractable fractions of heavy metals in sewage sludge. J Hazard Mater 106:133-137 
Kaschl A, Römheld V, Chen Y (2002) The influence of soluble organic matter from municipal solid waste compost on trace metal leaching in calcareous soils. Sci Total Environ 291:45-57

Keller A, Schulin R (2003) Modelling heavy metal and phosphorus balances for farming systems. Nutr Cycl Agroecosyst 66:271-284

Khan S, Cao Q, Zheng YM, Huang YZ, Zhu YG (2008) Health risks of heavy metals in contaminated soils and food crops irrigated with wastewater in Beijing, China. Environ Pollut 152:686-692

Kidd PS, Domínguez-Rodríguez MJ, Díez J, Monterroso C (2007) Bioavailability and plant accumulation of heavy metals and phosphorus in agricultural soils amended by long-term application of sewage sludge. Chemosphere 66:1458-1467

Ko HJ, Kim KY, Kim HT, Kim CN, Umeda M (2008) Evaluation of maturity parameters and heavy metal contents in composts made from animal manure. Waste Manage 28:813-820

Korboulewsky N, Dupouyet S, Bonin G (2002) Environmental risks of applying sewage sludge compost to vineyards: carbon, heavy metals, nitrogen, and phosphorus accumulation. J Environ Qual $31: 1522-1527$

Krishnamurti GSR, Naidu R (2002) Solid-solution speciation and phytoavailability of copper and zinc in soils. Environ Sci Technol 36:2645-2651

LăcătuşuR, Răuță C, Cărstea S, Ghelase I (1996) Soil-plant-man relationships in heavy metal polluted areas in Romania. Appl Geochem 11:105-107

Lakhdar A, Hafsi C, Rabhi M, Debez A, Montemurro F, Abdelly C, Jedidi N, Ouerghi Z (2008) Application of municipal solid waste compost reduces the negative effects of saline water in Hordeum maritimum L. Bioresour Technol 99:7160-7167

Larchevêque M, Ballini C, Korboulewsky N, Montès N (2006) The use of compost in afforestation of Mediterranean areas: effects on soil properties and young tree seedlings. Sci Total Environ 369:220230

Lasheen MR, Ammar NS (2009) Assessment of metals speciation in sewage sludge and stabilized sludge from different wastewater treatment plants, Greater Cairo, Egypt. J Hazard Mater 164:740-749

Lipoth SL, Schoenau JJ (2007) Copper, zinc, and cadmium accumulation in two prairie soils and crops as influenced by repeated applications of manure. J Plant Nutr Soil Sci 170:378-386

López Fernández JI, Navarro González M, González Caicedo S (2000) Decontamination treatment of residual organic matter: achieved levels of heavy metals. Edafología 7:151-157 (in Spanish)

Madrid F, López R, Cabrera F (2007) Metal accumulation in soil after application of municipal solid waste compost under intensive farming conditions. Agric Ecosyst Environ 119:249-256

Manios T, Stentiford EI, Millner PA (2003) The effect of heavy metals accumulation on the chlorophyll concentration of Typha latifolia plants, growing in a substrate containing sewage sludge compost and 
watered with metaliferus water. Ecol Eng 20:65-74

Mbarki S, Labidi N, Mahmoudi H, Jedidi N, Abdelly C (2008) Contrasting effects of municipal compost on alfalfa growth in clay and in sandy soils: N, P, K, content and heavy metal toxicity. Bioresour Technol 99:6745-6750

Millares R, Beltrán EM, Porcel MA, Delgado MM, Beringola ML, Martín JV, Calvo R, Walter I (2002) Emergence of six crops treated with fresh and composted sewage sludge from waste treatment plants. Rev Int Contam Ambient 18:139-146 (in Spanish)

Millares R, Beltrán EM, Porcel MA, Beringola ML, Martín JV, Calvo R, Delgado MM (2003) Dehydrated sewage sludge compost from wastewater treatment plants, effect of their contribution to the development of olive pegs. Expoliva 2003. Foro del Oliva y el Medio Ambiente OLI-2007 (in Spanish). Available at: www. expoliva.com/expoliva2003. Accessed 27 January 2010

Moolenaar S, van der Zee SEATM, Lexmond TM (1997) Indicators of the sustainability of heavy-metal management in agroecosystems. Sci Total Environ 201:155-169

Moreno JL, Garcia C, Hernandez T, Ayuso M (1997) Application of composted sewage sludges contaminated with heavy metals to an agricultural soil: effect on lettuce growth. Soil Sci Plant Nutr $43: 565-573$

Nicholson FA, Chambers BJ, Williams JR, Unwind RJ (1999) Heavy metal contents of livestock feeds and animal manures in England and Wales. Bioresour Technol 23:23-31

Nomeda S, Valdas P, Chen S-Y, Lin J-G (2008) Variations of metal distribution in sewage sludge composting. Waste Manage 28:1637-1644

Odlare M, Pell M, Svensson K (2008) Changes in soil chemical and microbiological properties during 4 years of application of various organic residues. Waste Manage 28:1246-1253

Oleszczuk P (2008) Phytotoxicity of municipal sewage sludge composts related to physico-chemical properties, PAHs and heavy metals. Ecotoxicol Environ Saf 69:496-505

ORNL (2004) Guidance for conducting risk assessments and related risk activities for the DOE-ORO Environmental Management Program, BJC/OR-271, Oak Ridge National Laboratory, Oak Ridge

ORNL (2010) Risk Assessment Information System (RAIS), Oak Ridge National Laboratory, Oak Ridge. Available at: http://rais. ornl.gov/

Paradelo Núñez R, Devesa Rey R, Moldes Menduíña AB, Barral Silva MT (2007) Physiologically based extraction of heavy metals in compost: preliminary results. J Trace Elem Med Biol 21:83-85

Pascual JA, Hernandez T, Garcia C, Ayuso M (1998) Enzymatic activities in an arid soil amended with urban organic wastes: laboratory experiment. Bioresour Technol 64:131-138

Pathak A, Dastidar MG, Sreekrishnan TR (2009) Bioleaching of heavy metals from sewage sludge: a review. J Environ Manage 90:2343-2353 
Pengcheng G, Xinbao T, Yanan T, Yingxu C (2008) Application of sewage sludge compost on highway embankments. Waste Manage 28:1630-1636

Petersen SO, Sommer SG, Béline F, Burton C, Dach J, Dourmad JY, Leip A, Misselbrook T, Nicholson F, Poulsen HD, Provolo G, Sørensen P, Vinnerås B, Weiske A, Bernal M-P, Böhm R, Juhász C, Mihelic R (2007) Recycling of livestock manure in a wholefarm perspective. Livest Sci 112:180-191

Pichtel J, Anderson M (1997) Trace metal bioavailability in municipal solid waste and sewage sludge compost. Bioresour Technol 60:223-229

Pinamonti F, Stringari G, Gasperi F, Zorzi G (1997) The use of compost: its effects on heavy metal levels in soil and plants. Resour Conserv Recycl 21:129-143

Planquart P, Bonin G, Prone A, Massiani C (1999) Distribution, movement and plant availability of trace metals in soils amended with sewage sludge composts: application to low metal loadings. Sci Total Environ 241:161-179

Qazi MA, Akram M, Ahmad N, Artiola JF, Tuller M (2009) Economical and environmental implications of solid waste compost applications to agricultural fields in Punjab, Pakistan. Waste Manage 29:2437-2445

Ramadurai J, Shapiro C, Kozloff M, Telfer M (1993) Zinc abuse and sideroblastic anemia. Am J Hematol 42:227-228

Ramos MC (2006) Metals in vineyard soils of the Penedès area (NE Spain) after compost application. J Environ Manage 78:209-215

Río M, Franco-Uría A, Abad E, Roca E (2011) A risk-based decision tool for the management of organic waste in agriculture and farming activities (FARMERS). J Hazard Mater 185:792-800

Roca-Pérez L, Martínez C, Marcilla P, Boluda R (2009) Composting rice straw with sewage sludge and compost effects on the soil- plant system. Chemosphere 75:781-787

Rosal A, Pérez JP, Arcos MA, Dios M (2007) Impact of heavy metals in compost of municipal solid wastes and in its agriculture use in Spain. Información Tecnológica 18:75-82 (in Spanish)

Sager M (2007) Trace and nutrient elements in manure, dung and compost samples in Austria. Soil Biol Biochem 39:1383-1390

Salazar FJ, Saldana RC (2007) Characterization of manures from fish cage farming in Chile. Bioresour Technol 98:3322-3327

Salcedo-Pérez E, Vázquez-Alarcón A, Krishnamurthy L, Zamora-Natera F, Hernández-Álvarez E, Rodríguez Macias R (2007) Evaluation of sewage sludge as organic fertilizer in volcanic soils used for agriculture and forestry in Jalisco, México. INCI 32:115-120 (in Spanish)

Sauvé S, McBride MB, Hendershot WH (1997) Speciation of lead in contaminated soils. Environ Pollut 98:149-155 
Sauvé S, Hendershot W, Herbert EA (2000) Solid-state solution partitioning of metals in polluted soil: dependence on $\mathrm{pH}$, the total burden of metals and organic matter. Environ Sci Technol 34:11251131

Saviozzi A, Biasci A, Riffaldi R, Levi-Minzi R (1999) Long-term effects of farmyard manure and sewage sludge on some soil biochemical characteristics. Biol Fertil Soils 30:100-106

Schroth AW, Bostick BC, Kaste JM, Friedland AJ (2008) Lead sequestration and species redistribution during soil organic matter decomposition. Environ Sci Technol 42:3627-3633

Sebastiaò JM, Queda ACC (2003) Composting of urban solid wastes: agronomic interest vs environmental impact. Application to potato production. Residuos 13:98-104 (in Spanish)

Singh RP, Agrawal M (2008) Potential benefits and risks of land application of sewage sludge. Waste Manage 28:347-358

Smith SR (1994) Effect of soil pH on availability to crops of metals in sewage sludge-treated soils. I. Nickel, copper and zinc uptake and toxicity to ryegrass. Environ Pollut 85:321-327

Smith SR (2009) A critical review of the bioavailability and impacts of heavy metals in municipal solid waste composts compared to sewage sludge. Environ Int 35:142-156

Smith KM, Abrahams PW, Dagleish MP, Steigmajer J (2009) The intake of lead and associated metals by sheep grazing miningcontaminated floodplain pastures in mid-Wales, UK: I. Soil ingestion, soilmetal partitioning and potential availability to pasture herbage and livestock. Sci Total Environ 407:3731-3739

Soliva M, Paulet S (2001) Composting of organic wastes and agricultural application. In: Boixadeira J, Teira MR (eds) Agricultural aplication of organic wastes. University of Lleida, Spain, pp 63-78 (in Spanish)

Sörme L, Lagerkvist R (2002) Sources of heavy metals in urban wastewater in Stockholm. Sci Total Environ 298:131-145

Soumaré M, Demeyer A, Tack FMG, Verloo MG (2002) Chemical characteristics of Malian and Belgian solid waste composts. Bioresour Technol 81:97-101

Spanish Government (2005) RD 824/2005, adaptation of Commission Regulation (EC) no. 2003/2003 of 13 October 2003 on fertilisers, 8 July 2005

Sridhara Cari N, Kamala CT, Suman Raj DS (2008) Assessing risk of heavy metals from consuming food grown on sewage irrigated soils and food chain transfer. Ecotoxicol Environ Saf 69:513-524

Stylianou MA, Inglezakis VJ, Moustakas KG, Loizidou MD (2008) Improvement of the quality of sewage sludge compost by adding natural clinoptilolite. Desalination 224:240-249

Tejada M, García-Martínez AM, Parrado J (2009) Effects of a vermicompost composted with beet vinasse on soil properties, soil losses and soil restoration. Catena 77:238-247 
Tripathy S, Bhattacharyya P, Equeenuddin SM, Kim K, Kulkarni HD (2008) Comparison of microbial indicators under two water regimes in a soil amended with combined paper mill sludge and decomposed cow manure. Chemosphere 71:168-175

US EPA (2010), Integrated Risk Information System (IRIS). Available at: http:/www.epa.gov/iris/

Walter I, Martínez F, Cala V (2006) Heavy metal speciation and phytotoxic effects of three representative sewage sludges for agricultural uses. Environ Pollut 139:507-514

Weber J, Karczewska A, Drozd J, Licznar M, Licznar S, Jamroz E, Kocowicz A (2007) Agricultural and ecological aspects of a sandy soil as affected by the application of municipal solid waste composts. Soil Biol Biochem 39:294-1302

Wong JWC, Ma KK, Fang KM, Cheung C (1999) Utilization of a manure compost for organic farming in Hong Kong. Bioresour Technol 67:43-46

Zheljazkov VD, Astatkie T, Caldwell CD, MacLeod J, Grimmett M (2006) Compost, manure, and gypsum application to timothy/red clover forage. J Environ Qual 35:2410-2418

Zheng GD, Chen TB, Gao D, Luo W (2004) Dynamic of lead speciation in sewage sludge composting. Water Sci Technol 50:75-82

Zhuang P, McBride MB, Xia H, Li N, Li Z (2009) Health risk from heavy metals via consumption of food crops in the vicinity of Dabaoshan mine, South China. Sci Total Environ 407:1551-1561

Zorpas AA, Inglezakis VJ, Loizidou M (2008) Heavy metals fractionation before, during and after composting of sewage sludge with natural zeolite. Waste Manage 28:2054-2060

Zubillaga MS, Bressan E, Lavado RS (2008) Heavy metal mobility in polluted soils: effect of different treatments. Am J Environ Sci 4:620-624 
Table 1 Metal content inventory, metal hazard quotient (HQ), and hazard index (HI) of composts

\begin{tabular}{|c|c|c|c|c|c|c|c|c|c|c|c|c|c|c|}
\hline \multirow{2}{*}{$\begin{array}{l}\text { Compost } \\
\text { Source }\end{array}$} & \multirow[t]{2}{*}{ Origin and feedstock materials } & \multirow[t]{2}{*}{ Country } & \multicolumn{5}{|c|}{ Heavy metal content $(\mathrm{mg} / \mathrm{kg})$} & \multirow[t]{2}{*}{ Data reported } & \multicolumn{5}{|l|}{$\mathrm{HQ}$} & \multirow[t]{2}{*}{$\mathrm{HI}$} \\
\hline & & & $\mathrm{Cd}$ & $\mathrm{Cu}$ & $\mathrm{Ni}$ & $\mathrm{Pb}$ & $\mathrm{Zn}$ & & $\mathrm{Cd}$ & $\mathrm{Cu}$ & $\mathrm{Ni}$ & $\mathrm{Pb}$ & $\mathrm{Zn}$ & \\
\hline \multirow[t]{2}{*}{$\begin{array}{l}\text { Pinamonti et al. } \\
1997\end{array}$} & $\begin{array}{l}\text { (MSW) MSW compost from the composting of the organic } \\
\text { fraction of unseparated MSW, selected mechanically at the } \\
\text { plant }\end{array}$ & \multirow[t]{2}{*}{ Italy } & 3.2 & 437 & 140 & 652 & 1,228 & Mean & 0.017 & 0.074 & 0.147 & 0.075 & 0.428 & 0.751 \\
\hline & $\begin{array}{l}\text { (SS+B) Compost produced at the plant through the treatment of } \\
\text { a mixture of urban wastewater }\end{array}$ & & 1.2 & 184 & 25 & 81 & 512 & Mean & 0.012 & 0.045 & 0.039 & 0.019 & 0.239 & 0.354 \\
\hline \multirow[t]{2}{*}{$\begin{array}{l}\text { Pichtel and } \\
\text { Anderson } 1997\end{array}$} & $\begin{array}{l}\text { (MSW) Composted MSW prepared from municipal wastes that } \\
\text { were processed first by manual techniques to remove non- } \\
\text { recyclable materials. The compostable fraction included food } \\
\text { and yard wastes, paper products, and other organic solids. The } \\
\text { solids were exposed to in-vessel biological digesters for } \\
\text { pretreatment ( } 3 \text { days), then transferred to piles, where they were } \\
\text { composted by the turned-pile } \\
\text { method for several weeks }\end{array}$ & \multirow[t]{2}{*}{ USA } & - & 236 & 28.0 & 210.0 & 655 & Single value & - & 0.051 & 0.041 & 0.032 & 0.282 & 0.406 \\
\hline & $\begin{array}{l}\text { (SS) The sludge, derived from primarily domestic wastewater, } \\
\text { was an aerobically digested and then composted by the aerated- } \\
\text { pile method }\end{array}$ & & - & 269 & 40 & 340 & 770 & Single value & - & 0.055 & 0.052 & 0.045 & 0.314 & 0.466 \\
\hline $\begin{array}{l}\text { Bazzoffi et al. } \\
1998\end{array}$ & $\begin{array}{l}\text { (MSW) Compost was produced through a pile aerobic } \\
\text { maturation process lasting } 2 \text { months, starting from urban refuse } \\
\text { biomass that was ground after removal of plastics and metals } \\
\text { by mechanical sieving and magnetic separators. The } \\
\text { composition of the compost was dominated by non-metallic } \\
\text { inerts, especially glass and shell fragments }\end{array}$ & Italy & 9.1 & 248 & 28 & 626 & 540 & Single value & 0.031 & 0.053 & 0.041 & 0.073 & 0.248 & 0.446 \\
\hline $\begin{array}{l}\text { Hyun et al. } \\
1998\end{array}$ & $\begin{array}{l}\text { (SS) The SS compost was obtained from the Joint Water } \\
\text { Pollution Control Plant, in one batch, then stored indoors in air- } \\
\text { dried conditions }\end{array}$ & USA & 61 & 475 & 250 & 1,100 & 3,500 & Single value & 0.132 & 0.078 & 0.260 & 0.118 & 0.973 & 1.561 \\
\hline $\begin{array}{l}\text { Pascual et al. } \\
1998\end{array}$ & $\begin{array}{l}\text { (MSW+SS) Compost made by a mixture (ratio, } 1: 1 \text { in organic } \\
\text { matter) of MSW and SS }\end{array}$ & Spain & 3.0 & 158 & 221 & 198 & 535 & Single value & 0.017 & 0.042 & 0.230 & 0.031 & 0.246 & 0.566 \\
\hline \multirow[t]{3}{*}{$\begin{array}{l}\text { Baldwin and } \\
\text { Shelton } 1999\end{array}$} & $\begin{array}{l}(\mathrm{MSW}+\mathrm{SS}) \text { The co-compost of MSW and SS was produced by } \\
\text { an aerobic, in-vessel process }\end{array}$ & \multirow[t]{3}{*}{ USA } & 2.9 & 215 & 40 & 203 & 738 & Single value & 0.017 & 0.049 & 0.052 & 0.032 & 0.305 & 0.455 \\
\hline & (MSW) The compost of MSW was produced in windrows & & 1.0 & 53 & 18 & 34 & 96 & Single value & 0.012 & 0.027 & 0.033 & 0.014 & 0.099 & 0.185 \\
\hline & $\begin{array}{l}\text { (SS) The SS compost was produced from centrifuged, } \\
\text { dewatered SS mixed with wood chips and straw in a ratio of } \\
1: 5: 1\end{array}$ & & 2.1 & 173 & 16 & 88 & 499 & Single value & 0.015 & 0.044 & 0.031 & 0.020 & 0.235 & 0.345 \\
\hline $\begin{array}{l}\text { Hackett et al. } \\
1999\end{array}$ & $\begin{array}{l}\text { (SS FA) Combined primary and secondary sludge and power } \\
\text { boiler FA from the mill and mixed to yield a } 50: 50 \text { (v/v) } \\
\text { mixture of sludge and ash. The pile was left to compost in a } \\
\text { static windrow. The compost was produced on an old landfill } \\
\text { site with a functional leachate collection system to ensure that } \\
\text { all leachate produced was treated at the mill's wastewater } \\
\text { treatment plant. This site was wind exposed, requiring spraying }\end{array}$ & Canada & 0.006 & 34.8 & 17.7 & 5.5 & 64.5 & Single value & 0.009 & 0.024 & 0.032 & 0.011 & 0.086 & 0.162 \\
\hline
\end{tabular}




\begin{tabular}{|c|c|c|c|c|c|c|c|c|c|c|c|c|c|c|}
\hline & $\begin{array}{l}\text { of water on the compost pile during the summer months for } \\
\text { dust control and to maintain optimal moisture }(50 \%)\end{array}$ & & & & & & & & & & & & & \\
\hline $\begin{array}{l}\text { Wong et al. } \\
1999\end{array}$ & $\begin{array}{l}\text { (Manure) The manure compost originated from livestock } \\
\text { wastes mixed with sawdust followed by a composting period of } \\
60 \text { days }\end{array}$ & China & 1.65 & 143 & - & 26.1 & 475 & Mean & 0.013 & 0.039 & - & 0.013 & 0.228 & 0.293 \\
\hline $\begin{array}{l}\text { García-Gil et } \\
\text { al. } 2000\end{array}$ & $\begin{array}{l}\text { (MSW) MSW compost was obtained from the Valdemingómez } \\
\text { Municipal Waste Treatment Plant in Madrid }\end{array}$ & Spain & $<0.2$ & 548 & 81 & 681 & 1,325 & Single value & 0.009 & 0.085 & 0.090 & 0.078 & 0.463 & 0.725 \\
\hline \multirow{15}{*}{$\begin{array}{l}\text { Soliva and } \\
\text { Paulet } 2001\end{array}$} & (SS) Compost obtained from a mixture of SS and GW & \multirow[t]{15}{*}{ Spain } & 0.4 & 171 & 123 & 16 & 493 & Single value & 0.010 & 0.043 & 0.130 & 0.012 & 0.233 & 0.428 \\
\hline & (SS) Compost obtained from a mixture of SS and GW & & 1.5 & 338 & 54 & 110 & 1,087 & Single value & 0.013 & 0.063 & 0.065 & 0.022 & 0.401 & 0.564 \\
\hline & (SS) Compost obtained from a mixture of SS and GW & & 1.2 & 237 & 26 & 86 & 644 & Single value & 0.012 & 0.051 & 0.040 & 0.020 & 0.278 & 0.401 \\
\hline & (SS) Compost obtained from a mixture of SS and GW & & 0.48 & 55 & 33 & 59 & 260 & Single value & 0.010 & 0.027 & 0.046 & 0.017 & 0.159 & 0.259 \\
\hline & (SS) Compost obtained from a mixture of SS and GW & & 5.66 & 220 & 62 & 462 & 2,886 & Single value & 0.023 & 0.049 & 0.072 & 0.057 & 0.836 & 1.037 \\
\hline & (GW) Compost obtained from GW treatment & & 0.4 & 62 & 13 & 46 & 201 & Single value & 0.010 & 0.028 & 0.028 & 0.016 & 0.138 & 0.220 \\
\hline & (GW) Compost obtained from GW treatment & & 0.1 & 66 & 89 & 39 & 101 & Single value & 0.009 & 0.029 & 0.097 & 0.015 & 0.101 & 0.251 \\
\hline & (GW) Compost obtained from GW treatment & & 5.14 & 97 & 36 & 52 & 1,459 & Single value & 0.022 & 0.034 & 0.048 & 0.016 & 0.497 & 0.617 \\
\hline & (GW) Compost obtained from $\mathrm{GW}$ treatment & & 0.17 & 42 & 47 & 38 & 76 & Single value & 0.009 & 0.025 & 0.058 & 0.015 & 0.091 & 0.198 \\
\hline & $\begin{array}{l}\text { (MSW) Compost obtained from MSW. Selection of organic } \\
\text { fraction with GW }\end{array}$ & & 0.3 & 325 & 82.0 & 97 & 197 & Single value & 0.010 & 0.062 & 0.091 & 0.021 & 0.137 & 0.321 \\
\hline & $\begin{array}{l}\text { (MSW) Compost obtained from MSW. Selection of organic } \\
\text { fraction and GW }\end{array}$ & & 0.3 & 100 & 81.0 & 66 & 247 & Single value & 0.010 & 0.034 & 0.090 & 0.018 & 0.154 & 0.306 \\
\hline & $\begin{array}{l}\text { (MSW) Compost obtained from MSW. Organic fraction } \\
\text { mechanically separated }\end{array}$ & & 0.9 & 271 & 192 & 118 & 396 & Single value & 0.011 & 0.055 & 0.199 & 0.023 & 0.203 & 0.491 \\
\hline & $\begin{array}{l}\text { (MSW) Compost obtained from MSW. Organic fraction } \\
\text { mechanically separated }\end{array}$ & & 1.35 & 399 & 101 & 324 & 1,462 & Single value & 0.013 & 0.070 & 0.109 & 0.044 & 0.498 & 0.734 \\
\hline & $\begin{array}{l}\text { (MSW) Compost obtained from MSW. Organic fraction } \\
\text { mechanically separated }\end{array}$ & & 1.06 & 342 & 94.0 & 97 & 732 & Single value & 0.012 & 0.063 & 0.102 & 0.021 & 0.304 & 0.502 \\
\hline & $\begin{array}{l}\text { (MSW) Compost obtained from MSW. Selection of organic } \\
\text { fraction and GW from gardens and parks of Barcelona }\end{array}$ & & 0.4 & 42 & 27.0 & 38 & 192 & Single value & 0.010 & 0.025 & 0.041 & 0.015 & 0.135 & 0.226 \\
\hline \multirow[t]{4}{*}{$\begin{array}{l}\text { Greenway and } \\
\text { Song } 2002\end{array}$} & $\begin{array}{l}\text { (MSW) The municipal composting site was used for GW } \\
\text { (grass and leaves) compost obtained from an open-air windrow- } \\
\text { composting system. It was used for composting }\end{array}$ & \multirow[t]{4}{*}{ UK } & 1.5 & 50.2 & 15 & 117.2 & 220.4 & Mean & 0.013 & 0.027 & 0.030 & 0.023 & 0.145 & 0.238 \\
\hline & $\begin{array}{l}\text { (MSW) The municipal composting site was used for } \\
\text { composting GW mixed with sewage sludge. The compost was } \\
\text { obtained from an open-air windrow composting system }\end{array}$ & & 3.2 & 140.3 & 16.5 & 133.5 & 354.6 & Mean & 0.017 & 0.039 & 0.031 & 0.025 & 0.190 & 0.302 \\
\hline & $\begin{array}{l}\text { (MSW) The municipal composting site was used for compost } \\
\text { from farmer's vegetable waste. The compost was obtained } \\
\text { from an open-air windrow-composting system }\end{array}$ & & 0.2 & 10.8 & 5.8 & 13.7 & 25.9 & Mean & 0.009 & 0.020 & 0.022 & 0.012 & 0.070 & 0.133 \\
\hline & $\begin{array}{l}\text { (MSW) The municipal composting site was used for } \\
\text { composting of mainly green (woody) waste. The compost was } \\
\text { obtained from an open-air windrow composting system }\end{array}$ & & 0.18 & 10.7 & 5.7 & 17.3 & 35.8 & Mean & 0.009 & 0.020 & 0.022 & 0.012 & 0.074 & 0.137 \\
\hline $\begin{array}{l}\text { Kaschl et al. } \\
2002\end{array}$ & $\begin{array}{l}\text { (MSW) MSW compost was obtained from a commercial } \\
\text { composting plant. The duration of composting was } 100 \text { days }\end{array}$ & Israel & 4.2 & 756 & 134 & 337 & 743 & Single value & 0.020 & 0.106 & 0.141 & 0.045 & 0.307 & 0.619 \\
\hline Korboulewsky & $(\mathrm{SS}+\mathrm{B}+\mathrm{GW})$ The $\mathrm{SS}$, a by-product of municipal wastewater & France & 0.8 & 101 & 12 & 34.0 & 221 & Mean & 0.011 & 0.034 & 0.028 & 0.014 & 0.145 & 0.232 \\
\hline
\end{tabular}




\begin{tabular}{|c|c|c|c|c|c|c|c|c|c|c|c|c|c|c|}
\hline et al. 2002 & $\begin{array}{l}\text { treatment, was mixed with pine bark and GW. The mixture was } \\
\text { composted for } 30 \text { days at } 75^{\circ} \mathrm{C} \text { to kill pathogenic } \\
\text { microorganisms and decompose phytotoxic substances, then } \\
\text { sieved to remove large bark pieces and stored in swathes. The } \\
\text { swathes were turned (mixed) several times over } 6 \text { months to } \\
\text { promote organic matter humification }\end{array}$ & & & & & & & & & & & & & \\
\hline $\begin{array}{l}\text { Millares et al. } \\
2002\end{array}$ & $\begin{array}{l}\text { (SS) Compost obtained from SS of five wastewater treatment } \\
\text { plants of Madrid. The compost was subject to aerobic } \\
\text { composting for } 3 \text { months, with periodic dump, without } \\
\text { structuring agent }\end{array}$ & Spain & 5 & 332 & 64 & 371 & 2,857 & Single value & 0.022 & 0.062 & 0.074 & 0.048 & 0.830 & 1.036 \\
\hline \multirow{2}{*}{$\begin{array}{l}\text { Soumaré et al. } \\
2002\end{array}$} & (MSW) Farm compost & Mali & $<\mathrm{dl}$ & 10.3 & 6.5 & 3.4 & 110 & Mean & - & 0.020 & 0.023 & 0.011 & 0.104 & 0.158 \\
\hline & (MSW) Compost from an industrial composter & Belgium & $<\mathrm{dl}$ & 31 & 13 & 80 & 470 & Mean & - & 0.023 & 0.028 & 0.019 & 0.226 & 0.296 \\
\hline $\begin{array}{l}\text { Manios et al. } \\
2003\end{array}$ & $\begin{array}{l}\text { (SS) The SS compost was produced by Thames Water Plc } \\
\text { using a Windrow system with SS and straw on a 1:1 basis by } \\
\text { volume (v/v) }\end{array}$ & Greece & 1.5 & 525 & 68 & 189 & 825 & Single value & 0.013 & 0.083 & 0.078 & 0.030 & 0.330 & 0.534 \\
\hline $\begin{array}{l}\text { Millares et al. } \\
2003\end{array}$ & $\begin{array}{l}\text { (SS) The compost was obtained from SS of five wastewater } \\
\text { treatment plants of Madrid }\end{array}$ & Spain & $<3$ & 330 & 67 & 140 & 1,390 & Single value & 0.017 & 0.062 & 0.077 & 0.025 & 0.480 & 0.661 \\
\hline $\begin{array}{l}\text { Sebastiaò and } \\
\text { Queda } 2003\end{array}$ & $\begin{array}{l}\text { (MSW) The compost was obtained by bio-oxidation process of } \\
\text { organic matter, over } 60 \text { days, in a locked ward, in trapezoidal } \\
\text { aerated piles, with stirring and correction moisture }\end{array}$ & Portugal & 2.4 & 293 & - & 247 & 448 & Mean & 0.015 & 0.058 & - & 0.036 & 0.220 & 0.329 \\
\hline \multirow[t]{2}{*}{ Goi et al. 2006} & $\begin{array}{l}\text { (MSW) Compost originated from the wet fraction of two } \\
\text { different MSW and was collected from bags that were to be } \\
\text { sold for agricultural purposes. The compost was selected from } \\
\text { waste mixtures with poor characteristics }\end{array}$ & \multirow[t]{2}{*}{ Italy } & $<2.0$ & 49.9 & 25.0 & 127.4 & 126.8 & Mean & 0.014 & 0.027 & 0.039 & 0.024 & 0.111 & 0.215 \\
\hline & $\begin{array}{l}\text { (MSW) Compost originated from the wet fraction of two } \\
\text { different MSW and was collected from bags that were to be } \\
\text { sold for agricultural purposes. The compost was chosen from a } \\
\text { high quality compost product certified by the producer }\end{array}$ & & $<2.0$ & 74.2 & 21.0 & 92.6 & 198.4 & Mean & 0.014 & 0.030 & 0.035 & 0.020 & 0.137 & 0.236 \\
\hline $\begin{array}{l}\text { Larchevêque et } \\
\text { al. } 2006\end{array}$ & $\begin{array}{l}\text { (SS+GW) This compost was elaborated with } \mathrm{GW}(1 / 3 \text { volume), } \\
\text { pine barks }(1 / 3 \text { volume), and local municipal } \mathrm{SS}(1 / 3 \text { volume). } \\
\text { The mixture was composted for } 30 \text { days at } 75^{\circ} \mathrm{C} \text { to kill } \\
\text { pathogenic microorganisms and decompose phytotoxic } \\
\text { substances, and then sieved to remove large barkpieces and } \\
\text { stored in swathes. The swathes were mixed several times in } 6 \\
\text { months to promote organic matter humification }\end{array}$ & France & 0.77 & 122 & 14.7 & 65 & 266 & Mean & 0.011 & 0.037 & 0.030 & 0.018 & 0.161 & 0.257 \\
\hline Ramos 2006 & (Manure) Composted cattle manure & Spain & 0.8 & 35 & - & 9.8 & 142 & Mean & 0.011 & 0.024 & - & 0.012 & 0.117 & 0.164 \\
\hline $\begin{array}{l}\text { Walter et al. } \\
2006\end{array}$ & $\begin{array}{l}\text { (SS) The composted sludge was obtained from an an } \\
\text { aerobically digested sludge mixed with pine barkat an initial } \\
\text { sludge/wood ratio of } 1: 1.5 \mathrm{v} / \mathrm{v} \text {. Composting was performed in } \\
\text { the open air at a private facility, turning the piles periodically } \\
\text { twice during the first month and then monthly until the end of } \\
\text { the process. The final solid content was approximately } 65-\end{array}$ & Spain & 3.5 & 220 & 42.5 & 179 & 820 & Mean & 0.018 & 0.049 & 0.054 & 0.029 & 0.328 & 0.478 \\
\hline
\end{tabular}




\begin{tabular}{|c|c|c|c|c|c|c|c|c|c|c|c|c|c|c|}
\hline & $67 \%$ & & & & & & & & & & & & & \\
\hline $\begin{array}{l}\text { Zheljazkov et } \\
\text { al. } 2006\end{array}$ & $\mathrm{MSW}+\mathrm{SS}$ & Canada & - & 114 & - & 75.0 & 280 & Single value & - & 0.036 & - & 0.019 & 0.165 & 0.220 \\
\hline $\begin{array}{l}\text { Casado-Vela et } \\
\text { al. } 2007\end{array}$ & $\begin{array}{l}\text { (SS) Aerobically composted SS from a waste water treatment } \\
\text { facility was used. It was composted in the plant using a three- } \\
\text { step process involving: firstly, air drying of sewage sludge and } \\
\text { addition of sawdust; secondly, turning of the feedstock every } 7 \\
\text { days to promote aeration; and finally, mechanical mixing of the } \\
\text { feedstock and collection after } 3 \text { months of stabilization }\end{array}$ & Spain & 1.6 & 157 & - & 40.8 & 470 & Single value & 0.013 & 0.042 & - & 0.015 & 0.226 & 0.296 \\
\hline \multirow[t]{3}{*}{$\begin{array}{l}\text { Madrid et al. } \\
2007\end{array}$} & $\begin{array}{l}\text { (MSW) Compost obtained from the MSW treatment plant of } \\
\text { Villarrasa (SW Spain) }\end{array}$ & \multirow[t]{3}{*}{ Spain } & $\overline{-}$ & 128 & 23 & 98 & 261 & Mean & - & 0.038 & 0.037 & 0.021 & 0.159 & 0.255 \\
\hline & $\begin{array}{l}\text { (MSW) Compost was obtained from the MSW treatment plant } \\
\text { of Villarrasa (SW Spain) }\end{array}$ & & - & 312 & 54 & 172 & 494 & Mean & - & 0.060 & 0.065 & 0.028 & 0.234 & 0.387 \\
\hline & $\begin{array}{l}\text { (MSW) Compost obtained from the MSW treatment plant of } \\
\text { Villarrasa (SW Spain) }\end{array}$ & & \begin{tabular}{|l}
- \\
-
\end{tabular} & 244 & 39 & 203 & 512 & Mean & - & 0.052 & 0.051 & 0.032 & 0.239 & 0.374 \\
\hline \multirow[t]{4}{*}{$\begin{array}{l}\text { Paradelo Núñez } \\
\text { et al. } 2007\end{array}$} & $\begin{array}{l}\text { (MSW) MSW compost obtained by anaerobic fermentation of } \\
\text { the biodegradable fraction of MSW, separated before } \\
\text { collection, followed by an aerobic composting step }\end{array}$ & \multirow[t]{4}{*}{ Spain } & 3.5 & 325 & 57 & 188 & 608 & Mean & 0.018 & 0.062 & 0.067 & 0.030 & 0.268 & 0.445 \\
\hline & $\begin{array}{l}\text { (MSW) Aerobic MSW compost obtained from the source } \\
\text { separated organic fraction of MSW }\end{array}$ & & 3.1 & 829 & 75 & 223 & 1,149 & Mean & 0.017 & 0.114 & 0.084 & 0.034 & 0.417 & 0.666 \\
\hline & $\begin{array}{l}\text { (MSW+GW) Commercial compost obtained from source } \\
\text { separated MSW mixed with GW }\end{array}$ & & 2.1 & 52 & 25 & 62 & 100 & Mean & 0.015 & 0.027 & 0.039 & 0.017 & 0.138 & 0.236 \\
\hline & $\begin{array}{l}\text { (SS+GW) Compost obtained from municipal garden trimmings } \\
\text { mixed with SS }\end{array}$ & & 2.7 & 688 & 71 & 180 & 896 & Mean & 0.016 & 0.100 & 0.80 & 0.029 & 0.349 & 0.574 \\
\hline \multirow[t]{3}{*}{$\begin{array}{l}\text { Rosal et al. } \\
2007\end{array}$} & $\begin{array}{l}\text { (MSW) A compost pile, with } 20 \mathrm{t} \text {, was periodically turned and } \\
\text { moistened as necessary for } 140 \text { days to ensure biological } \\
\text { stability. Compost obtained during first year of the experiment }\end{array}$ & \multirow[t]{3}{*}{ Spain } & 3.0 & 276 & 50 & 165 & 415 & Single value & 0.017 & 0.056 & 0.061 & 0.028 & 0.209 & 0.371 \\
\hline & $\begin{array}{l}\text { (MSW) A compost pile, with } 20 \mathrm{t} \text {, was periodically turned and } \\
\text { moistened as necessary for } 140 \text { days to ensure biological } \\
\text { stability. Compost obtained during second year of the } \\
\text { experiment }\end{array}$ & & 3.0 & 252 & 57 & 120 & 579 & Single value & 0.017 & 0.053 & 0.067 & 0.023 & 0.259 & 0.419 \\
\hline & $\begin{array}{l}\text { (MSW) A compost pile, with } 20 \mathrm{t} \text {, was periodically turned and } \\
\text { moistened as necessary for } 140 \text { days to ensure biological } \\
\text { stability. Compost obtained during third year of the experiment }\end{array}$ & & 2.0 & 373 & 64 & 144 & 603 & Single value & 0.014 & 0.067 & 0.074 & 0.026 & 0.266 & 0.447 \\
\hline Sager 2007 & 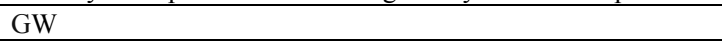 & Austria & 0.43 & 100 & 25.7 & 43.4 & 267 & Median & 0.010 & 0.034 & 0.039 & 0.015 & 0.161 & 0.259 \\
\hline \multirow[t]{2}{*}{$\begin{array}{l}\text { Weber et al. } \\
2007\end{array}$} & $\begin{array}{l}\text { (MSW) Commercial compost from Katowice produced by the } \\
\text { MUT-DANO system represents MSWs originating from a } \\
\text { highly industrialized region }\end{array}$ & \multirow[t]{2}{*}{ Poland } & 11.7 & 366 & 168 & 972 & 1,825 & Single value & 0.037 & 0.066 & 0.175 & 0.106 & 0.588 & 0.972 \\
\hline & $\begin{array}{l}\text { (MSW) Commercial compost from Zywiec produced by the } \\
\text { HERHOFF system, utilized selectively collected MSWs rich in } \\
\text { organic carbon }\end{array}$ & & 3.3 & 34 & 41 & 65.0 & 228 & Single value & 0.018 & 0.024 & 0.053 & 0.018 & 0.148 & 0.261 \\
\hline Alvarenga et al. & (MSW) Compost from the organic fraction of unsorted MSW, & Portugal & 4.3 & 357 & 56 & 269 & 583 & Mean & 0.020 & 0.065 & 0.067 & 0.038 & 0.260 & 0.450 \\
\hline
\end{tabular}




\begin{tabular}{|c|c|c|c|c|c|c|c|c|c|c|c|c|c|c|}
\hline \multirow[t]{2}{*}{2008} & \multirow{2}{*}{$\begin{array}{l}\text { obtained in a composting plant near Setúbal (Portugal) } \\
\text { (GW) Garden waste compost from a composting plant in Tavira } \\
\text { (Portugal), which receives source separated garden residues } \\
\text { (namely grass clippings, leaves and brush), were used }\end{array}$} & & \multirow[b]{2}{*}{1.4} & \multirow[b]{2}{*}{14} & \multirow[b]{2}{*}{16} & \multirow[b]{2}{*}{34} & \multirow[b]{2}{*}{35} & \multirow[b]{2}{*}{ Mean } & \multirow[b]{2}{*}{0.013} & \multirow[b]{2}{*}{0.020} & \multirow[b]{2}{*}{0.031} & \multirow[b]{2}{*}{0.014} & \multirow[b]{2}{*}{0.074} & \multirow[b]{2}{*}{0.152} \\
\hline & & & & & & & & & & & & & & \\
\hline $\begin{array}{l}\text { Jordan et al. } \\
2008\end{array}$ & SM & Ireland & $\begin{array}{l}6.254 \\
5.8 \\
10.4 \\
143 \\
\end{array}$ & 54 & 5.8 & 10.4 & 143 & $\begin{array}{l}\text { Mean }(63 \\
\text { samples of } \\
\text { SM) }\end{array}$ & 0.025 & 0.027 & 0.022 & 0.012 & 0.117 & 0.203 \\
\hline Ko et al. 2008 & $\begin{array}{l}\text { (Manure) Compost consisted of sawdust as the bulking agent } \\
\text { and animal manures at 10:90 v/vratios. Animal manures were } \\
\text { composed of } 50 \% \text { dairy manure (collected on an open feedlot } \\
\text { using a wheel loader), } 30 \% \text { beef manures (collected in a } \\
\text { sawdust bed barn using a wheel loader) and } 20 \% \text { swine manure } \\
\text { (collected at a mechanical manure separator) collected from an } \\
\text { integrated live stock experimental building }\end{array}$ & Korea & 1.1 & 466 & 11 & 38.2 & 566 & Mean & 0.012 & 0.077 & 0.027 & 0.015 & 0.255 & 0.386 \\
\hline $\begin{array}{l}\text { Lakhdar et al. } \\
2008\end{array}$ & $\begin{array}{l}\text { (MSW) The compost was mechanically produced by mixing } \\
\text { weekly the waste heap under aerobicconditions by fast } \\
\text { fermentation }\end{array}$ & Tunisia & 3.37 & 91.63 & - & 251.63 & 290.19 & Mean & 0.018 & 0.033 & - & 0.036 & 0.169 & 0.256 \\
\hline $\begin{array}{l}\text { Mbarki et al. } \\
2008\end{array}$ & MSW & Tunisia & 2.56 & 278 & - & 668 & 649 & Single value & 0.016 & 0.056 & - & 0.077 & 0.280 & 0.429 \\
\hline \multirow[t]{3}{*}{$\begin{array}{l}\text { Oleszczuk } \\
2008\end{array}$} & $\begin{array}{l}\text { (SS) SS was composted during } 76 \text { days. Ventilation was } \\
\text { provided through air distribution tubes. In order to increase } \\
\text { oxygen inflow, the composted material was additionally mixed } \\
\text { once a fortnight }\end{array}$ & & 76 & 236 & 177.5 & 37.5 & 1,270 & Mean & 0.160 & 0.051 & 0.185 & 0.015 & 0.449 & 0.860 \\
\hline & $\begin{array}{l}\text { (SS) SS was composted during } 76 \text { days. Ventilation was } \\
\text { provided through air distribution tubes. In order to increase } \\
\text { oxygen inflow, the composted material was additionally mixed } \\
\text { once a fortnight }\end{array}$ & & 1.95 & 314 & 17.7 & 35.2 & 1,125 & Mean & 0.014 & 0.060 & 0.032 & 0.014 & 0.411 & 0.531 \\
\hline & $\begin{array}{l}\text { (SS) SS was composted during } 76 \text { days. Ventilation was } \\
\text { provided through air distribution tubes. In order to increase } \\
\text { oxygen inflow, the composted material was additionally mixed } \\
\text { once a fortnight }\end{array}$ & & 2.75 & 155 & 58 & 37.8 & 938 & Mean & 0.016 & 0.041 & 0.068 & 0.015 & 0.360 & 0.500 \\
\hline $\begin{array}{l}\text { Pengcheng et } \\
\text { al. } 2008\end{array}$ & SS+GW & China & 3.72 & 156 & - & 61.9 & 1,105 & Single value & 0.019 & 0.041 & - & 0.017 & 0.406 & 0.483 \\
\hline $\begin{array}{l}\text { Zubillaga et al. } \\
2008\end{array}$ & MSW & Argentina & $<4.0$ & 727 & 109 & 383 & 1,183 & Single value & 0.019 & 0.104 & 0.117 & 0.049 & 0.426 & 0.715 \\
\hline $\begin{array}{l}\text { Achiba et al. } \\
2009\end{array}$ & $\begin{array}{l}\text { (MSW) The MSW was prepared from a mixture of the } \\
\text { separated and shredded organic fraction of household rubbish } \\
\text { and garden waste by aerobic fermentation }\end{array}$ & Tunisia & 3.3 & 278 & 44 & 325 & 410 & Mean & 0.018 & 0.056 & 0.056 & 0.044 & 0.208 & 0.382 \\
\hline $\begin{array}{l}\text { Businelli et al. } \\
2009\end{array}$ & MSW & Italy & 50.0 & 240 & 52 & 750 & 647 & Mean & 0.022 & 0.052 & 0.063 & 0.085 & 0.279 & 0.501 \\
\hline $\begin{array}{l}\text { Cherif et al. } \\
2009\end{array}$ & $\begin{array}{l}\text { (MSW) MSW compost obtained from sorted MSW by aerobic } \\
\text { composting process for } 120 \text { days }\end{array}$ & Tunisia & 2.3 & 337 & 90.8 & 80.1 & 290 & $\begin{array}{l}\text { Mean (the } \\
\text { values }\end{array}$ & 0.015 & 0.063 & 0.099 & 0.019 & 0.169 & 0.365 \\
\hline
\end{tabular}




\begin{tabular}{|c|c|c|c|c|c|c|c|c|c|c|c|c|c|c|}
\hline & & & & & & & & $\begin{array}{l}\text { reported are } \\
\text { the means of } \\
\text { four } \\
\text { replicates) }\end{array}$ & & & & & & \\
\hline \multirow[t]{3}{*}{$\begin{array}{l}\text { Farrell and } \\
\text { Jones } 2009 b\end{array}$} & $\begin{array}{l}\text { (MSW) MSW compost was produced in the EcoPOD } \\
\text { experiment }\end{array}$ & \multirow[t]{3}{*}{ UK } & 0.69 & 261 & 46 & 614 & 249 & Mean & 0.011 & 0.054 & 0.057 & 0.072 & 0.155 & 0.349 \\
\hline & $\begin{array}{l}\text { (MSW+GW) MSW compost was produced in the EcoPOD } \\
\text { experiment }\end{array}$ & & 0.49 & 276 & 37 & 232 & 213 & Mean & 0.010 & 0.056 & 0.049 & 0.034 & 0.142 & 0.291 \\
\hline & $\begin{array}{l}\text { (GW) GW compost derived from source separated municipal } \\
\text { GW waste was obtained from Flintshire County Council's open } \\
\text { windrow-composting facility at Greenfields, Flintshire, UK }\end{array}$ & & 1.30 & 63 & 20 & 198 & 369 & Mean & 0.013 & 0.029 & 0.034 & 0.031 & 0.195 & 0.302 \\
\hline $\begin{array}{l}\text { Haroun et al. } \\
2009\end{array}$ & $\begin{array}{l}\text { (TSS) The sludge }(100 \mathrm{~kg}) \text { was mixed with sawdust }(50 \mathrm{~kg}) \text {, } \\
\text { chicken manure }(30 \mathrm{~kg}) \text {, beneficial organisms }(1 \mathrm{l}) \text { and rice } \\
\text { bran }(20 \mathrm{~kg}) \text { in a pile on a composting windrow type. With the } \\
\text { aim of maintaining aerobic conditions during the process, the } \\
\text { pile was turned manually every } 10 \text { days. The mature compost } \\
\text { was obtained at the end of } 60 \text { days of composting }\end{array}$ & Malaysia & 1.6 & 54.0 & & 22 & 148 & Single value & 0.013 & 0.027 & - & 0.011 & 0.119 & 0.170 \\
\hline Qazi et al. 2009 & $\begin{array}{l}\text { (MSW) The compost was originated from recycled mixed } \\
\text { MSW. Windrow composting is applied to generate the compost }\end{array}$ & Pakistan & 34 & 480 & 39 & 73 & 1,622 & Single value & 0.082 & 0.078 & 0.060 & 0.018 & 0.538 & 0.776 \\
\hline $\begin{array}{l}\text { Roca-Pérez et } \\
\text { al. } 2009\end{array}$ & $\begin{array}{l}\text { (SS+GW) The compost included SS and rice straw and the } \\
\text { composting during } 90 \text { days }\end{array}$ & Spain & 1.2 & 170 & 36 & 94 & 700 & Mean & 0.012 & 0.043 & 0.048 & 0.021 & 0.295 & 0.419 \\
\hline \multirow[t]{2}{*}{$\begin{array}{l}\text { Tejada et al. } \\
2009\end{array}$} & $\begin{array}{l}\text { (GW) The vermin compost was obtained using green forages } \\
\text { (constituted basically by grasses, green vegetable leaves, herbs } \\
\text { and plant materials) as substrate }\end{array}$ & \multirow[t]{2}{*}{ Spain } & $<0.1$ & 1.4 & $<0.1$ & $<0.1$ & 3.2 & $\begin{array}{l}\text { Mean (data are } \\
\text { the means of } \\
\text { five samples) }\end{array}$ & 0.009 & 0.018 & 0.018 & 0.011 & 0.059 & 0.115 \\
\hline & $\begin{array}{l}\text { (GW+BV) The compost was obtained by the co- composting of } \\
\text { the beet vinasse and the vermicompost at a 1:1 rate } \\
\text { (weight/weight) }\end{array}$ & & $<0.1$ & 2.5 & $<0.1$ & $<0.1$ & 12.8 & $\begin{array}{l}\text { Mean (data are } \\
\text { the means of } \\
\text { five samples) }\end{array}$ & 0.009 & 0.018 & 0.018 & 0.011 & 0.064 & 0.120 \\
\hline Mean & & & 4.4 & 222.7 & 55.0 & 181.3 & 644.0 & & 0.019 & 0.048 & 0.067 & 0.029 & 0.266 & 0.420 \\
\hline Min & & & 0.06 & 1.4 & 0.1 & 0.1 & 3.2 & & 0.009 & 0.018 & 0.018 & 0.011 & $\begin{array}{c}0.059 \\
\end{array}$ & 0.115 \\
\hline Max & & & 76 & 829 & 250 & 1,100 & 3,500 & & 0.160 & 0.114 & 0.260 & 0.118 & 0.973 & 1.561 \\
\hline
\end{tabular}

MSW municipal solid waste, SS sewage sludge, GW green waste, FA fly ash, B bark, SM spent mushroom, TSS tannery sewage sludge, BV beet vinasse 
Table 2 Metal content inventory, metal hazard quotient (HQ), and hazard index (HI) of sludge and other wastes

\begin{tabular}{|c|c|c|c|c|c|c|c|c|c|c|c|c|c|c|}
\hline \multirow[t]{2}{*}{ Sludge Source } & \multirow[t]{2}{*}{ Origin and feedstock materials } & \multirow[t]{2}{*}{ Country } & \multicolumn{5}{|c|}{ Heavy metal content (mg/kg) } & \multirow[t]{2}{*}{ Data reported } & \multicolumn{5}{|l|}{ HQ } & \multirow[t]{2}{*}{$\mathrm{HI}$} \\
\hline & & & $\mathrm{Cd}$ & $\mathrm{Cu}$ & $\mathrm{Ni}$ & $\mathrm{Pb}$ & $\mathrm{Zn}$ & & $\mathrm{Cd}$ & $\mathrm{Cu}$ & $\mathrm{Ni}$ & $\mathrm{Pb}$ & $\mathrm{Zn}$ & \\
\hline $\begin{array}{l}\text { Moreno et al. } \\
1997\end{array}$ & $\begin{array}{l}\text { (MSW+SS) The SS base originated from an } \\
\text { aerobic sewage treatment plant receiving } \\
\text { municipal and food industry effluents. In this } \\
\text { treatment plant, sewage is submitted to a } \\
\text { biological-type depuration process }\end{array}$ & & 2.0 & 275 & 105 & - & 776 & Single value & 0.014 & 0.056 & 0.113 & - & 0.316 & 0.499 \\
\hline \multirow[t]{2}{*}{$\begin{array}{l}\text { Pascual et al. } \\
1998\end{array}$} & $\begin{array}{l}\text { (SS) The SS was obtained from an Spain } \\
\text { aerobic-treatment }\end{array}$ & & 6.0 & 151 & 228 & 85 & 415 & Single value & 0.024 & 0.041 & 0.237 & 0.020 & 0.209 & 0.531 \\
\hline & (MSW) Organic fraction of MSW & & 2.0 & 77 & 178 & 77 & 281 & Single value & 0.014 & 0.031 & 0.185 & 0.019 & 0.166 & 0.415 \\
\hline $\begin{array}{l}\text { Fang and Wong } \\
1999\end{array}$ & $\begin{array}{l}\text { (SS) Dewatered an aerobically digested SS } \\
\text { was collected from the Tai Po sewage } \\
\text { treatment plant }\end{array}$ & China & - & 785 & 72.5 & - & 2,786 & $\begin{array}{l}\text { Mean (the values } \\
\text { reported are the } \\
\text { means of } \\
\text { triplicates) }\end{array}$ & - & 0.109 & 0.082 & - & 0.813 & 1.004 \\
\hline $\begin{array}{l}\text { Saviozzi et al. } \\
1999\end{array}$ & SS & Italy & 4.0 & 236 & 40 & 60 & 1,640 & $\begin{array}{l}\text { Mean (the values } \\
\text { reported are the } \\
\text { means of } \\
\text { triplicates) }\end{array}$ & 0.019 & 0.051 & 0.052 & 0.017 & 0.542 & 0.681 \\
\hline \multirow{2}{*}{$\begin{array}{l}\text { López } \\
\text { Fernández et al. } \\
2000\end{array}$} & $\begin{array}{l}\text { (SS) SS obtained from waste water treatment } \\
\text { plant of Burgos }\end{array}$ & \multirow[t]{2}{*}{ Spain } & 4.84 & 148.27 & 46.91 & 158.52 & $1,023.37$ & Single value & 0.022 & 0.040 & 0.058 & 0.027 & 0.384 & 0.531 \\
\hline & $\begin{array}{l}\text { (MSW) Urban wastes obtained from municipal } \\
\text { landfill of Burgos }\end{array}$ & & 5.48 & 251.80 & 87.81 & 626.56 & 716.65 & Single value & 0.023 & 0.053 & 0.096 & 0.073 & 0.299 & 0.544 \\
\hline \multirow[t]{3}{*}{ Cole et al. 2001} & $\begin{array}{l}\text { (SS) SS were derived from uncontaminated } \\
\text { sludge }\end{array}$ & \multirow[t]{3}{*}{ UK } & 1.94 & 722 & 45 & 161 & 725 & Mean & 0.014 & 0.103 & 0.057 & 0.027 & 0.302 & 0.503 \\
\hline & (SS) SS were derived from Zn-rich sludge & & 17.2 & 1,438 & 629 & 1,075 & 6,691 & Mean & 0.049 & 0.171 & 0.691 & 0.0115 & 1.630 & 2.656 \\
\hline & (SS) SS derived from Cd-rich sludge & & 48.9 & 617 & 188 & 494 & 1,244 & Mean & 0.110 & 0.093 & 0.195 & 0.060 & 0.442 & 0.900 \\
\hline \multirow[t]{2}{*}{ Illera et al. 2001} & $\begin{array}{l}\text { (SS) The SS was obtained from Spain waste } \\
\text { water treatment plant of Madrid, mainly urban } \\
\text { origin. It was obtained from anaerobic } \\
\text { digestion }\end{array}$ & & 0.6 & 174 & 15.3 & 252 & 445 & Single value & 0.011 & 0.044 & 0.036 & 0.030 & 0.184 & 0.310 \\
\hline & $\begin{array}{l}\text { (MSW) The MSW was obtained from waste } \\
\text { treatment plant of Valdemingómez (Madrid) } \\
\text { and correspond to organic fraction composted } \\
\text { of domestic wastes }\end{array}$ & & 1.5 & 203 & 21.6 & 191 & 335 & Single value & 0.013 & 0.047 & 0.036 & 0.030 & 0.184 & 0.310 \\
\hline \multirow{5}{*}{$\begin{array}{l}\text { Soliva and } \\
\text { Paulet } 2001\end{array}$} & IS & \multirow[t]{5}{*}{ Spain } & 0.20 & 166 & 59 & 15 & 521 & Single value & 0.009 & 0.043 & 0.069 & 0.012 & 0.242 & 0.375 \\
\hline & IS & & 0.30 & 110 & 6 & 16 & 683 & Single value & 0.010 & 0.035 & 0.023 & 0.012 & 0.290 & 0.370 \\
\hline & IS & & 0.50 & 49 & 63 & 15 & 87 & Single value & 0.010 & 0.026 & 0.073 & 0.012 & 0.095 & 0.216 \\
\hline & IS & & 2.5 & 1,140 & 38 & 30 & 2,993 & Single value & 0.016 & 0.0143 & 0.050 & 0.014 & 0.860 & 1.083 \\
\hline & (MSW) Organic fraction of MSW & & 2.0 & 156 & 53 & 190 & 569 & Single value & 0.014 & 0.041 & 0.064 & 0.030 & 0.256 & 0.405 \\
\hline
\end{tabular}




\begin{tabular}{|c|c|c|c|c|c|c|c|c|c|c|c|c|c|c|}
\hline & (MSW) Organic fraction of MSW & & 0.12 & 14 & 15 & 6 & 43 & Single value & 0.009 & 0.020 & 0.031 & 0.011 & 0.077 & 0.148 \\
\hline $\begin{array}{l}\text { Millares et al. } \\
2002\end{array}$ & $\begin{array}{l}\text { (SS) Fresh SS obtained from wastewater } \\
\text { treatment plant of Viveros }\end{array}$ & Spain & 1.0 & 197 & 15 & 197 & 577 & Single value & 0.012 & 0.047 & 0.030 & 0.031 & 0.259 & 0.379 \\
\hline $\begin{array}{l}\text { Acosta et al. } \\
2003\end{array}$ & $\begin{array}{l}\text { (SS) SS obtained from waste water treatment } \\
\text { plant of Punta Cardón }\end{array}$ & Venezuela & 3.7 & 206.6 & 28.1 & 253 & 878.6 & Mean & 0.019 & 0.048 & 0.042 & 0.037 & 0.345 & 0.491 \\
\hline $\begin{array}{l}\text { Chicón Reina } \\
2003\end{array}$ & $\begin{array}{l}\text { (SS) SS obtained from urban wastewater } \\
\text { treatment plant }\end{array}$ & Spain & 3.3 & 250 & 125 & 365.7 & 864.9 & Single value & 0.018 & 0.053 & 0.132 & 0.048 & 0.341 & 0.592 \\
\hline $\begin{array}{l}\text { Manios et al. } \\
2003\end{array}$ & SS & UK & 1.2 & 599 & 99 & 191 & 728 & Single value & 0.012 & 0.091 & 0.107 & 0.030 & 0.303 & 0.543 \\
\hline $\begin{array}{l}\text { Millares et al. } \\
2003\end{array}$ & $\begin{array}{l}\text { (SS) Mixture of SS obtained from } 5 \\
\text { wastewater treatment plants of Madrid }\end{array}$ & Spain & 1.2 & 339 & 70 & 64 & 1,650 & Single value & 0.012 & 0.063 & 0.079 & 0.017 & 0.545 & 0.716 \\
\hline \multirow[t]{4}{*}{$\begin{array}{l}\text { Fuentes et al. } \\
2004\end{array}$} & $\begin{array}{l}\text { (SS) SS came from waste water treatment } \\
\text { plant in the Region of Murcia. SS was } \\
\text { obtained from aerobic digestion }\end{array}$ & \multirow[t]{4}{*}{ Spain } & 1.10 & 204 & 17 & 58 & 487 & Mean & 0.012 & 0.047 & 0.032 & 0.017 & 0.232 & 0.340 \\
\hline & $\begin{array}{l}\text { (SS) SS came from wastewater treatment plant } \\
\text { in the Region of Murcia. SS was obtained an } \\
\text { aerobically }\end{array}$ & & 18.3 & 337 & 29 & 167 & 871 & Mean & 0.051 & 0.063 & 0.042 & 0.028 & 0.343 & 0.527 \\
\hline & $\begin{array}{l}\text { (SS) SS came from wastewaterl treatment } \\
\text { plant in the Region of Murcia. It was stabilized } \\
\text { in a waste stabilization pond }\end{array}$ & & 1.4 & 167 & 15 & 250 & 697 & Mean & 0.036 & 0.043 & 0.030 & 0.036 & 0.294 & 0.439 \\
\hline & $\begin{array}{l}\text { (SS) SS came from wastewater treatment plant } \\
\text { in the Region of Murcia. Non-stabilized SS }\end{array}$ & & 1.14 & 146 & 25 & 87 & 458 & Mean & 0.012 & 0.040 & 0.039 & 0.020 & 0.223 & 0.334 \\
\hline $\begin{array}{l}\text { Kandpal et al. } \\
2004\end{array}$ & $\begin{array}{l}\text { (SS) Bulk sample of SS was collected in } \\
\text { plastic bags from Karula drain of Moradabad, } \\
\text { UP, India, a city having brass plating and } \\
\text { policing industrial units. The sample was } \\
\text { processed to remove the non-recyclable } \\
\text { materials }\end{array}$ & India & 16 & $1,434.50$ & 168 & 340.5 & 2,164 & $\begin{array}{l}\text { Mean (the values } \\
\text { reported are the } \\
\text { means of } \\
\text { triplicate } \\
\text { samples) }\end{array}$ & 0.046 & 0.0171 & 0.0175 & 0.045 & 0.669 & 1.106 \\
\hline $\begin{array}{l}\text { Ahlberg et al. } \\
2006\end{array}$ & $\begin{array}{l}\text { (SS) SS was collected directly from } \\
\text { Ryaverken, the sewage works of Gothenburg, } \\
\text { Sweden. The sludge produced is digested an } \\
\text { aerobically and had } 29.2 \% \text { (by weight) dry } \\
\text { solids (DS) content. The organic content of DS } \\
\text { was } 54 \%\end{array}$ & Sweden & 1.64 & 501.9 & 24.7 & 43.79 & 748.7 & Mean & 0.013 & 0.081 & 0.039 & 0.015 & 0.308 & 0.456 \\
\hline $\begin{array}{l}\text { García et al. } \\
2006\end{array}$ & (SS) SS obtained from closed digestion & Venezuela & 6.8 & 226.01 & 76.46 & .04 .29 & $1,474.79$ & Mean & 0.026 & 0.050 & 0.086 & 0.042 & 0.501 & 0.705 \\
\hline \multirow[t]{2}{*}{ Goi et al. 2006} & $\begin{array}{l}\text { (SS) Sludge sample is representative of } 1 \\
\text { month of sludge production and come from } \\
\text { MWW treatment plants treating mainly } \\
\text { domestic wastewaters }\end{array}$ & \multirow[t]{2}{*}{ Italy } & $<2.0$ & 20.1 & 11.0 & 13.4 & 152.8 & Mean & 0.014 & 0.022 & 0.027 & 0.012 & 0.121 & 0.196 \\
\hline & $\begin{array}{l}\text { (SS) Sludge sample is representative of } 1 \\
\text { month of sludge production and come from } \\
\text { MWW treatment plants treating mainly }\end{array}$ & & $<2.0$ & 69.5 & 4.3 & 58.7 & 410.1 & Mean & 0.014 & 0.030 & 0.021 & 0.017 & 0.208 & 0.290 \\
\hline
\end{tabular}




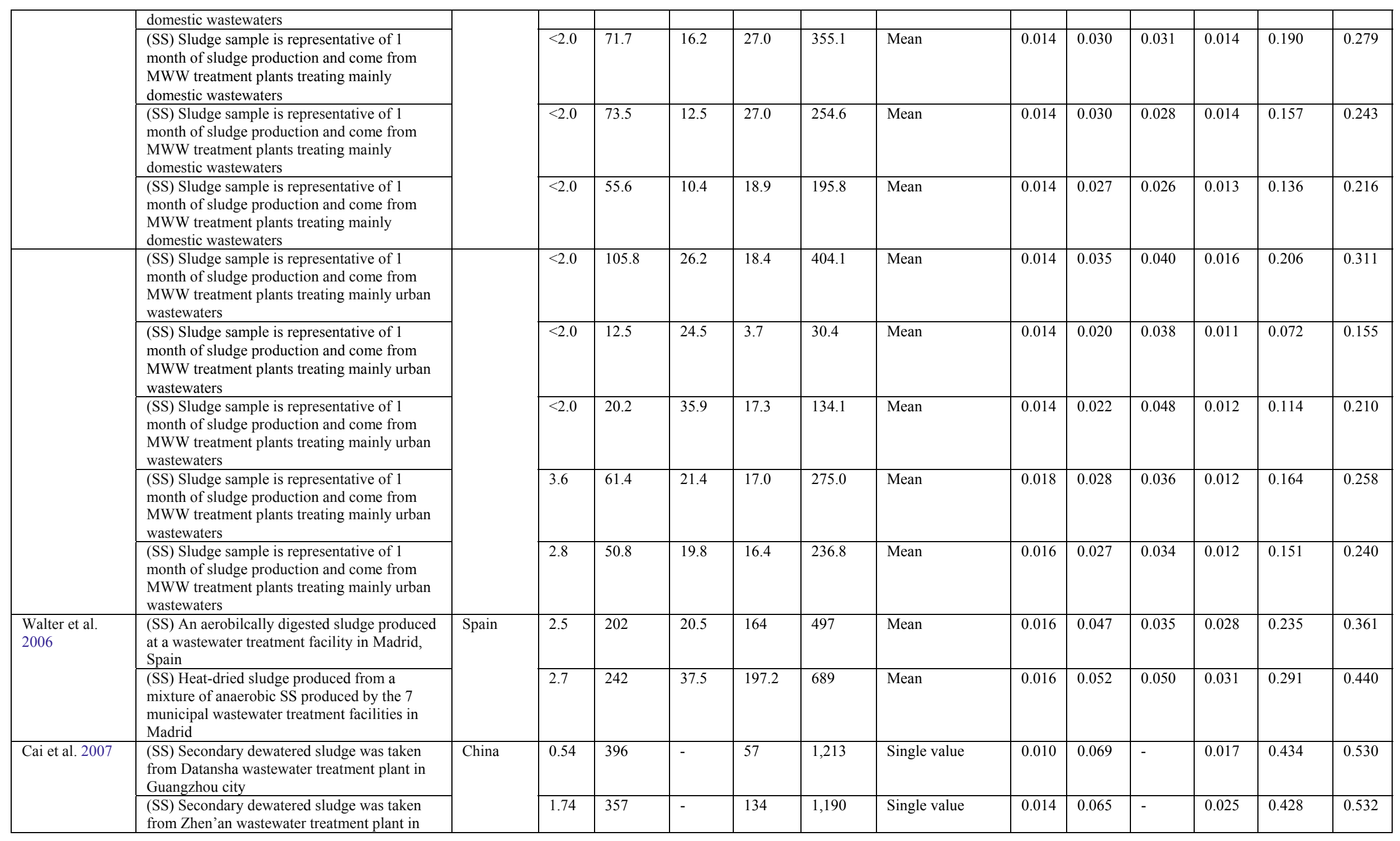




\begin{tabular}{|c|c|c|c|c|c|c|c|c|c|c|c|c|c|c|}
\hline & Foshan city & & & & & & & & & & & & & \\
\hline $\begin{array}{l}\text { Fuentes et al. } \\
2007\end{array}$ & $\begin{array}{l}\text { (SS) An aerobically digested SS from a } \\
\text { domestic wastewater treatment plant (Pinedo I, } \\
\text { located at the city of Valencia) }\end{array}$ & Spain & 3.3 & 406 & 47 & 182 & 1,306 & Single value & 0.018 & 0.071 & 0.058 & 0.029 & 0.387 & 0.583 \\
\hline Kidd et al. 2007 & (SS) Digested SS & Spain & $<5$ & 230 & 35.0 & 69.0 & 500.0 & Single value & 0.022 & 0.051 & 0.048 & 0.018 & 0.236 & 0.375 \\
\hline Sager 2007 & SS & Austria & 0.82 & 166 & 25.6 & 38.3 & 683 & Median & 0.011 & 0.043 & 0.039 & 0.015 & 0.290 & 0.398 \\
\hline $\begin{array}{l}\text { Salcedo-Pérez } \\
\text { et al. } 2007\end{array}$ & $\begin{array}{l}\text { (SS) SS collected from a wastewater treatment } \\
\text { plant of electronics manufacturing company of } \\
\text { the central region of Jalisco, México }\end{array}$ & México & 1.08 & 383.4 & 9.69 & 117.22 & 539.9 & Single value & 0.012 & 0.068 & 0.026 & 0.023 & 0.248 & 0.377 \\
\hline $\begin{array}{l}\text { Bose and } \\
\text { Bhattacharyya } \\
2008\end{array}$ & $\begin{array}{l}\text { (IS) Roadside sludge collected from pickling- } \\
\text { rolling and electroplating industrial area }\end{array}$ & India & 30.16 & 1,290 & 1,807 & 440 & 410 & Mean & 0.074 & 0.157 & 2.240 & 0.055 & 0.208 & 2.734 \\
\hline \multirow[t]{5}{*}{ Chen et al. 2008} & SS & \multirow[t]{5}{*}{ China } & 7.2 & 111 & - & 152 & 424.8 & Single value & 0.027 & 0.036 & - & 0.026 & 0.212 & 0.301 \\
\hline & SS & & 10.7 & 130.4 & - & 53.6 & 450.9 & Single value & 0.035 & 0.038 & - & 0.016 & 0.220 & 0.309 \\
\hline & SS & & 15.7 & 159.6 & - & 71.8 & 444.6 & Single value & 0.045 & 0.042 & - & 0.018 & 0.219 & 0.324 \\
\hline & SS & & 7.9 & 67 & - & 98.4 & 361 & Single value & 0.029 & 0.029 & - & 0.021 & 0.192 & 0.271 \\
\hline & $\begin{array}{l}\text { (IS+SS) The SS was collected from } \\
\text { Qingshuitang area in Zhuzhou, where many } \\
\text { chemical plants were centralized }\end{array}$ & & 903.8 & 659 & - & $1,270.2$ & $1,105.9$ & Single value & 1.536 & 0.097 & - & 0.134 & 0.406 & 2.173 \\
\hline \multirow[t]{12}{*}{ Hua et al. 2008} & $\begin{array}{l}\text { (SS) The SS was collected from the } \\
\text { wastewater treatment plant in Ningbo }\end{array}$ & \multirow[t]{12}{*}{ China } & 10.86 & 311.0 & 25.6 & 58.9 & $1,652.4$ & Single value & 0.035 & 0.060 & 0.039 & 0.017 & 0.546 & 0.697 \\
\hline & $\begin{array}{l}\text { (SS) The SS was collected from the } \\
\text { wastewater treatment plant in Fuyang }\end{array}$ & & 13.0 & 240.2 & 25.1 & 47.0 & $1,406.2$ & Single value & 0.040 & 0.052 & 0.039 & 0.016 & 0.484 & 0.631 \\
\hline & $\begin{array}{l}\text { (SS) The SS was collected from the } \\
\text { wastewater treatment plant in Lin'an }\end{array}$ & & 23.4 & 227.7 & 38.9 & 123.1 & $2,445.3$ & Single value & 0.061 & 0.050 & 0.051 & 0.024 & 0.735 & 0.921 \\
\hline & $\begin{array}{l}\text { (SS) The SS was collected from the } \\
\text { wastewater treatment plant in Shaoxing }\end{array}$ & & 13.3 & 452.3 & 54.2 & 72.8 & $2,231.3$ & Single value & 0.040 & 0.075 & 0.065 & 0.018 & 0.685 & 0.883 \\
\hline & $\begin{array}{l}\text { (SS) The SS was collected from the } \\
\text { wastewater treatment plant in Huzhou }\end{array}$ & & 2.1 & 220.1 & 42.7 & 93.7 & $1,521.4$ & Single value & 0.015 & 0.049 & 0.054 & 0.021 & 0.513 & 0.652 \\
\hline & $\begin{array}{l}\text { (SS) The SS was collected from the } \\
\text { wastewater treatment plant in JH }\end{array}$ & & 8.0 & 382.2 & 67.7 & 123.3 & $2,037.9$ & Single value & 0.029 & 0.068 & 0.077 & 0.024 & 0.639 & 0.837 \\
\hline & $\begin{array}{l}\text { (SS) The SS was collected from the } \\
\text { wastewater treatment plant in Lishui }\end{array}$ & & 3.7 & $1,191.3$ & 31.1 & 41.2 & $3,066.7$ & Single value & 0.019 & 0.148 & 0.044 & 0.015 & 0.877 & 1.103 \\
\hline & $\begin{array}{l}\text { (SS) The SS was collected from the } \\
\text { wastewater treatment plant in XS }\end{array}$ & & 16.8 & 861.5 & 106.6 & 162.7 & $2,678.6$ & Single value & 0.048 & 0.117 & 0.114 & 0.028 & 0.789 & 1.096 \\
\hline & $\begin{array}{l}\text { (SS) The SS was collected from the } \\
\text { wastewater treatment plant in Qige }\end{array}$ & & 19.4 & 266.2 & 102.3 & 195.1 & $2,431.6$ & Single value & 0.053 & 0.055 & 0.110 & 0.031 & 0.732 & 0.981 \\
\hline & $\begin{array}{l}\text { (SS) The SS was collected from the } \\
\text { wastewater treatment plant in Sibao }\end{array}$ & & 9.0 & 210.6 & 28.5 & 260.8 & $2,008.5$ & Single value & 0.031 & 0.048 & 0.042 & 0.037 & 0.632 & 0.790 \\
\hline & $\begin{array}{l}\text { (SS) The SS was collected from the } \\
\text { wastewater treatment plant in JJ }\end{array}$ & & 4.9 & 393.1 & 90.1 & 327.2 & $1,950.9$ & Single value & 0.022 & 0.069 & 0.098 & 0.044 & 0.618 & 0.851 \\
\hline & $\begin{array}{l}\text { (SS) The SS was collected from the } \\
\text { wastewater treatment plant in Huangyan }\end{array}$ & & 2.9 & 753.7 & 77.4 & 452.2 & $3,699.2$ & Single value & 0.017 & 0.0106 & 0.086 & 0.056 & 10.20 & 1.285 \\
\hline Oleszczuk 2008 & (SS) Dewatered SS were collected from & Poland & 1.9 & 201 & 21.7 & 59.5 & 1,385 & Mean & 0.014 & 0.047 & 0.036 & 0.017 & 0.478 & 0.592 \\
\hline
\end{tabular}




\begin{tabular}{|c|c|c|c|c|c|c|c|c|c|c|c|c|c|c|}
\hline & wastewater treatment plant & & & & & & & & & & & & & \\
\hline & $\begin{array}{l}\text { (SS) Dewatered SS were collected from } \\
\text { wastewater treatment plant }\end{array}$ & & 76 & 214 & 155 & 39.3 & 1,220 & Mean & 0.160 & 0.049 & 0.162 & 0.015 & 0.436 & 0.822 \\
\hline & $\begin{array}{l}\text { (SS) Dewatered SS were collected from } \\
\text { wastewater treatment plant }\end{array}$ & & 1.95 & 335 & 43.4 & 37.9 & 1,220 & Mean & 0.014 & 0.063 & 0.055 & 0.015 & 0.436 & 0.583 \\
\hline & $\begin{array}{l}\text { (SS) Dewatered SS were collected from } \\
\text { wastewater treatment plant }\end{array}$ & & 2.8 & 156 & 22.3 & 46.8 & 1,015 & Mean & 0.016 & 0.041 & 0.036 & 0.016 & 0.382 & 0.491 \\
\hline $\begin{array}{l}\text { Stylianou et al. } \\
2008\end{array}$ & $\begin{array}{l}\text { (SS) SS samples were collected from } \\
\text { wastewater treatment plant in Psittalia and } \\
\text { stored at } 4{ }^{\circ} \mathrm{C}\end{array}$ & Greece & - & 429 & 149 & 7.8 & 851 & $\begin{array}{l}\text { Mean (the values } \\
\text { reported are the } \\
\text { means of } \\
\text { triplicates) }\end{array}$ & - & 0.073 & 0.156 & 0.011 & 0.337 & 0.577 \\
\hline $\begin{array}{l}\text { Zorpas et al. } \\
2008\end{array}$ & $\begin{array}{l}\text { (SS) Dewatered an aerobically stabilized } \\
\text { primary SS, as result of primary treatment of } \\
\text { municipal wastewater along with industrial } \\
\text { wastes }\end{array}$ & Greece & 2.0 & 258 & 41 & 326.0 & 1,739 & Single value & 0.014 & 0.054 & 0.053 & 0.044 & 0.567 & 0.732 \\
\hline $\begin{array}{l}\text { Egiarte et al. } \\
2009\end{array}$ & $\begin{array}{l}\text { (SS) The anaerobic SS was obtained from the } \\
\text { Durango wastewater treatment plant }\end{array}$ & Spain & 5.7 & 456 & 208 & 151 & 10,924 & Single value & 0.024 & 0.076 & 0.216 & 0.026 & 2.470 & 2.812 \\
\hline \multirow[t]{2}{*}{$\begin{array}{l}\text { Haroun et al. } \\
2009\end{array}$} & $\begin{array}{l}\text { (TS) The TS was collected from Kenny } \\
\text { Leather Sdn Bhd (Melaka, Malaysia) }\end{array}$ & \multirow[t]{2}{*}{ Malaysia } & 8.0 & 80 & - & 10.0 & 200 & Single value & 0.029 & 0.031 & - & 0.012 & 0.0138 & 0.210 \\
\hline & (GW) Rice bran waste & & 0.2 & 24.33 & - & 1.2 & 127 & \begin{tabular}{|l} 
Single value \\
\end{tabular} & 0.009 & 0.022 & - & 0.011 & 0.111 & 0.153 \\
\hline \multirow[t]{5}{*}{$\begin{array}{l}\text { Lasheen and } \\
\text { Ammar } 2009\end{array}$} & IS+SS & \multirow[t]{5}{*}{ Egypt } & 3.02 & 197.70 & 39 & - & 1,770 & $\begin{array}{l}\text { Mean (the values } \\
\text { reported are the } \\
\text { means of } \\
\text { triplicates) }\end{array}$ & 0.017 & 0.047 & 0.051 & - & 0.575 & 0.690 \\
\hline & $\mathrm{IS}+\mathrm{SS}$ & & 2.56 & 311.23 & 55.80 & - & 515.40 & $\begin{array}{l}\text { Mean (the values } \\
\text { reported are the } \\
\text { means of } \\
\text { triplicates) }\end{array}$ & 0.016 & 0.060 & 0.066 & - & 0.240 & 0.382 \\
\hline & IS & & 3.42 & $1,391.42$ & 291.53 & - & $3,237.52$ & $\begin{array}{l}\text { Mean (the values } \\
\text { reported are the } \\
\text { means of } \\
\text { triplicates) }\end{array}$ & 0.018 & 0.167 & 0.305 & - & 0.915 & 1.405 \\
\hline & $\mathrm{IS}+\mathrm{SS}$ & & 3.56 & 200.20 & 56.30 & - & $1,181.62$ & $\begin{array}{l}\text { Mean (the values } \\
\text { reported are the } \\
\text { means of } \\
\text { triplicates) }\end{array}$ & 0.018 & 0.047 & 0.067 & - & 0.426 & 0.558 \\
\hline & $\mathrm{IS}+\mathrm{SS}$ & & 2.16 & 184.88 & 36.79 & - & 684.95 & $\begin{array}{l}\text { Mean (the values } \\
\text { reported are the } \\
\text { means of } \\
\text { triplicates) } \\
\end{array}$ & 0.015 & 0.045 & 0.049 & - & 0.290 & 0.399 \\
\hline $\begin{array}{l}\text { Roca-Pérez et } \\
\text { al. } 2009\end{array}$ & $\begin{array}{l}\text { (SS) Dewatered digested SS was collected } \\
\text { from the Metropolitan sewage industry } \\
\text { (EMARSA) }\end{array}$ & Spain & 2.55 & 230 & 53 & 50 & 1,100 & $\begin{array}{l}\text { Mean (the values } \\
\text { reported are the } \\
\text { means of } \\
\text { triplicates) }\end{array}$ & 0.016 & 0.051 & 0.064 & 0.016 & 0.404 & 0.551 \\
\hline Mean & & & 18.0 & 331.4 & 91.8 & 158.8 & $1,232.0$ & & 0.044 & 0.060 & 0.110 & 0.027 & 0.416 & 0.641 \\
\hline
\end{tabular}




\begin{tabular}{|l|l|l|l|l|l|l|l|l|l|l|l|l|l|l|l|l|l|l|l|l|l|}
\hline Min & & & 0.12 & 12.5 & 4.3 & 1.2 & 30.4 & & 0.009 & 0.020 & 0.021 & 0.011 & 0.072 & 0.148 \\
\hline $\operatorname{Max}$ & & & 903.8 & 1,438 & 1,807 & $1,270.2$ & 10,924 & & & 1.536 & 0.171 & 2.240 & 0.134 & 2.470 & 2.812 \\
\hline
\end{tabular}

SS sewage sludge; IS industrial sludge; TS tannery sludge; MWW municipal wastewater; MSW municipal solid waste; GW green waste 
Table 3 Metal content inventory, metal Hazard Quotient (HQ) and hazard index (HI) of manure

\begin{tabular}{|c|c|c|c|c|c|c|c|c|c|c|c|c|c|c|}
\hline \multirow[t]{2}{*}{ Manure Source } & \multirow[t]{2}{*}{ Origin and feed stock materials } & \multirow[t]{2}{*}{ Country } & \multicolumn{5}{|c|}{ Heavy metal content $(\mathrm{mg} / \mathrm{kg})$} & \multirow[t]{2}{*}{ Data reported } & \multicolumn{5}{|l|}{$\mathrm{HQ}$} & \multirow[t]{2}{*}{ HI } \\
\hline & & & $\mathrm{Cd}$ & $\mathrm{Cu}$ & $\mathrm{Ni}$ & $\mathrm{Pb}$ & $\mathrm{Zn}$ & & $\mathrm{Cd}$ & $\mathrm{Cu}$ & $\mathrm{Ni}$ & $\mathrm{Pb}$ & $\mathrm{Zn}$ & \\
\hline $\begin{array}{l}\text { Ayuso et al. } \\
1996\end{array}$ & $\begin{array}{l}\text { (Sheep) Manure (fresh organic material) from } \\
\text { sheep kept indoors }\end{array}$ & Spain & ND & 14 & 37 & 18 & 94 & Single value & - & 0.020 & 0.049 & 0.013 & 0.098 & 0.180 \\
\hline $\begin{array}{l}\text { Ihnat and } \\
\text { Fernandes } 1996\end{array}$ & $\begin{array}{l}\text { (Poultry) The materials used were from a } \\
\text { poultry manure aeration composting study } \\
\text { conducted with poultry manure slurry }\end{array}$ & Canada & 0.48 & 54.3 & 7 & 2.3 & 550 & Mean (2 samples were analyzed) & 0.010 & 0.027 & 0.023 & 0.011 & 0.251 & 0.322 \\
\hline $\begin{array}{l}\text { Pinamonti et al. } \\
1997\end{array}$ & $\begin{array}{l}\text { (Cattle) Un composted cattle manure } \\
\text { produced by dairy-cows in sheds with straw } \\
\text { bedding }\end{array}$ & Italy & 0.7 & 56 & 12 & 31 & 253 & Mean & 0.011 & 0.028 & 0.028 & 0.014 & 0.156 & 0.237 \\
\hline \multirow{8}{*}{$\begin{array}{l}\text { Nicholson et al. } \\
1999\end{array}$} & Dairy cattle farmyard & \multirow[t]{8}{*}{ UK } & 0.38 & 37.5 & 3.7 & 3.61 & 153 & Mean (6 samples were collected) & 0.010 & 0.025 & 0.021 & 0.011 & 0.121 & 0.188 \\
\hline & Dairy cattle slurry & & 0.33 & 62.3 & 5.4 & 4.87 & 209 & $\begin{array}{l}\text { Mean ( } 20 \text { samples were } \\
\text { collected) }\end{array}$ & 0.010 & 0.028 & 0.022 & 0.011 & 0.141 & 0.212 \\
\hline & Beef cattle farmyard & & 0.13 & 16.4 & 2.0 & 1.95 & 81 & $\begin{array}{l}\text { Mean (12 samples were } \\
\text { collected) }\end{array}$ & 0.009 & 0.021 & 0.016 & 0.011 & 0.093 & 0.153 \\
\hline & Beef cattle slurry & & 0.26 & 33.2 & 6.4 & 7.07 & 133 & Mean (8 samples were collected) & 0.010 & 0.024 & 0.023 & 0.011 & 0.113 & 0.181 \\
\hline & Pig farmyard & & 0.37 & 374 & 7.5 & 2.94 & 431 & Mean (7 samples were collected) & 0.010 & 0.067 & 0.024 & 0.011 & 0.214 & 0.326 \\
\hline & Pig slurry & & 0.30 & 351 & 10.4 & 2.48 & 575 & $\begin{array}{l}\text { Mean (12 samples were } \\
\text { collected) }\end{array}$ & 0.010 & 0.064 & 0.026 & 0.011 & 0.198 & 0.275 \\
\hline & Turkey litter & & 0.42 & 96.8 & 5.4 & 3.62 & 378 & $\begin{array}{l}\text { Mean (12 samples were } \\
\text { collected) }\end{array}$ & 0.010 & 0.034 & 0.022 & 0.011 & 0.198 & 0.275 \\
\hline & Layer manure & & 1.06 & 64.8 & 7.1 & 8.37 & 459 & Mean (8 samples were collected) & 0.012 & 0.029 & 0.023 & 0.012 & 0.223 & 0.299 \\
\hline $\begin{array}{l}\text { Saviozzi et al. } \\
1999\end{array}$ & Farmyard & Italy & 6.0 & 66 & 14 & 60 & 340 & $\begin{array}{l}\text { Mean (the values reported are the } \\
\text { means of triplicates) }\end{array}$ & 0.024 & 0.029 & 0.029 & 0.017 & 0.185 & 0.284 \\
\hline $\begin{array}{l}\text { García-Gil et al. } \\
2000\end{array}$ & Cow & Spain & $<0.2$ & $<3$ & 3 & $<3$ & 28 & Single value & 0.009 & 0.018 & 0.020 & 0.011 & 0.071 & 0.129 \\
\hline $\begin{array}{l}\text { Soliva and } \\
\text { Paulet } 2001\end{array}$ & Cow & Spain 0 & 0.24 & 59 & 46 & 8 & 219 & Single value & 0.009 & 0.028 & 0.057 & 0.011 & 0.144 & 0.249 \\
\hline \multirow{2}{*}{$\begin{array}{l}\text { Charest and } \\
\text { Beauchamp } \\
2002\end{array}$} & $\begin{array}{l}\text { (Poultry) Poultry manure came from a poultry } \\
\text { farm near St-Henri-de-Lévis }\end{array}$ & \multirow[t]{2}{*}{ Canada } & $<1$ & 160 & 12 & $<20$ & 550 & $\begin{array}{l}\text { Mean (chemical analyses were } \\
\text { done in triplicate) }\end{array}$ & 0.012 & 0.042 & 0.028 & 0.013 & 0.251 & 0.346 \\
\hline & $\begin{array}{l}\text { (Broiler litter) Poultry broiler floor litter came } \\
\text { from a poultry farm near St-Henri-de-Lévis }\end{array}$ & & $<1$ & 47 & $<10$ & $<20$ & 280 & $\begin{array}{l}\text { Mean (chemical analyses were } \\
\text { done in triplicate) }\end{array}$ & 0.012 & 0.026 & 0.026 & 0.013 & 0.165 & 0.242 \\
\hline $\begin{array}{l}\text { Acosta et al. } \\
2003\end{array}$ & $\begin{array}{l}\text { (Goat) Goat manure collected from local } \\
\text { breeding "El Taparo" }\end{array}$ & Venezuela & 1.0 & 13 & 4.4 & 3.7 & 71 & Mean & 0.012 & 0.020 & 0.021 & 0.011 & 0.089 & 0.153 \\
\hline $\begin{array}{l}\text { Zheljazkov et al. } \\
2006\end{array}$ & $\begin{array}{l}\text { (Mixture) The solid manure represents a } \\
\text { mixture of mostly cattle, sheep, and chicken } \\
\text { manures, plus some mink and fox manure }\end{array}$ & Canada & - & 8.3 & - & - & 91 & Single value & - & 0.019 & - & - & 0.097 & 0.116 \\
\hline $\begin{array}{l}\text { Clemente et al. } \\
2007\end{array}$ & $\begin{array}{l}\text { (Cow) Fresh cow manure was collected from } \\
\text { a cattle farm in Santomera (Murcia) }\end{array}$ & Spain & $<0.5$ & 26 & - & 9 & 12 & Single value & 0.010 & 0.023 & - & 0.012 & 0.064 & 0.109 \\
\hline Sager 2007 & Cattle & Austria & 0.27 & 51 & 6.3 & 4.1 & 164 & Median & 0.010 & 0.027 & 0.023 & 0.011 & 0.125 & 0.196 \\
\hline
\end{tabular}




\begin{tabular}{|c|c|c|c|c|c|c|c|c|c|c|c|c|c|c|}
\hline & Pig & & 0.46 & 282 & 12.5 & 1.9 & 1.156 & Median & 0.010 & 0.057 & 0.028 & 0.011 & 0.419 & 0.525 \\
\hline & Biogas & & 0.56 & 94 & 14.1 & 7.7 & 349 & Median & 0.010 & 0.033 & 0.029 & 0.011 & 0.188 & 0.271 \\
\hline $\begin{array}{l}\text { Salazar and } \\
\text { Saldana } 2007\end{array}$ & $\begin{array}{l}\text { (Trout) Trout manures collected from } \\
\text { raceways }\end{array}$ & Chile & 1.13 & 33.4 & 4.94 & 5.54 & 605 & Mean & 0.012 & 0.024 & 0.022 & 0.011 & 0.267 & 0.336 \\
\hline \multirow[t]{2}{*}{$\begin{array}{l}\text { Odlare et al. } \\
2008\end{array}$} & Pig+mineral N Sweden & & 0.3 & 140 & 4.0 & 1.0 & 631 & $\begin{array}{l}\text { Mean (the values represent mean } \\
\text { values for } 4 \text { years) }\end{array}$ & 0.010 & 0.039 & 0.021 & 0.011 & 0.275 & 0.356 \\
\hline & Cow+mineral $\mathrm{N}$ & & 0.4 & 76 & 7.0 & 4.0 & 415 & $\begin{array}{l}\text { Mean (the values represent mean } \\
\text { values for } 4 \text { years) }\end{array}$ & 0.010 & 0.031 & 0.023 & 0.011 & 0.209 & 0.284 \\
\hline $\begin{array}{l}\text { Tripathy et al. } \\
2008\end{array}$ & (Cow) Decomposed cow manure South Korea & & 0.5 & 10 & 4 & 21 & 21 & Single value & 0.010 & 0.020 & 0.021 & 0.013 & 0.068 & 0.132 \\
\hline $\begin{array}{l}\text { Achiba et al. } \\
2009\end{array}$ & $\begin{array}{l}\text { (Cow) The manure was taken from the cow- } \\
\text { shed of the experimental farm of the } \\
\text { Agronomic National Institute of Tunisia }\end{array}$ & Tunisia & 0.7 & 26 & 22 & 10.0 & 120 & Mean & 0.011 & 0.023 & 0.036 & 0.012 & 0.108 & 0.190 \\
\hline $\begin{array}{l}\text { Cherif et al. } \\
2009\end{array}$ & Farmyard & Tunisia & 2.10 & 25.50 & 22.40 & 8.90 & 117 & $\begin{array}{l}\text { Mean (the values reported are the } \\
\text { means of determinations made on } \\
4 \text { replicates) }\end{array}$ & 0.015 & 0.023 & 0.037 & 0.012 & 0.107 & 0.194 \\
\hline $\begin{array}{l}\text { Hachicha et al. } \\
2009\end{array}$ & $\begin{array}{l}\text { (Poultry) The poultry manure was collected } \\
\text { from an industrialized farm in the city of Sfax } \\
\text { (Tunisia) }\end{array}$ & Tunisia & $<4$ & 34 & $<88$ & $<41$ & 75 & Mean & 0.019 & 0.024 & 0.096 & 0.015 & 0.091 & 0.245 \\
\hline $\begin{array}{l}\text { Haroun et al. } \\
2009\end{array}$ & Chicken & Malaysia & 0.5 & 330 & - & 1.3 & 635 & Single value & 0.010 & 0.062 & - & 0.011 & 0.276 & 0.359 \\
\hline Mean & & & 0.90 & 88.2 & 14.0 & 10.9 & 306.5 & & 0.011 & 0.031 & 0.030 & 0.012 & 0.169 & 0.249 \\
\hline Min & & & 0.13 & 3 & 2 & 1 & 12 & & 0.009 & 0.018 & 0.019 & 0.011 & 0.064 & 0.109 \\
\hline Max & & & 6 & 374 & 88 & 60 & 1,156 & & 0.024 & 0.067 & 0.096 & 0.017 & 0.419 & 0.525 \\
\hline
\end{tabular}


Table 4 Parameter values for the distribution model

\begin{tabular}{llr} 
Parameter & Units & Value \\
\hline Application rate & $\mathrm{t} \cdot \mathrm{ha}^{-1} \cdot \mathrm{year}^{-1}$ & 10 \\
$\mathrm{Cd}$ (initial) in soil & $\mathrm{mg} \cdot \mathrm{kg}^{-1}$ & 1.0 \\
$\mathrm{Cu}$ (initial) in soil & $\mathrm{mg} \cdot \mathrm{kg}^{-1}$ & 19.3 \\
$\mathrm{Ni}$ (initial) in soil & $\mathrm{mg} \cdot \mathrm{kg}^{-1}$ & 11.1 \\
$\mathrm{~Pb}$ (initial) in soil & $\mathrm{mg} \cdot \mathrm{kg}^{-1}$ & 33.0 \\
$\mathrm{Zn}$ (initial) in soil & $\mathrm{mg} \cdot \mathrm{kg}^{-1}$ & 42.4 \\
Average pasture production & $\mathrm{kg} \cdot \mathrm{ha}^{-1} \cdot \mathrm{year}^{-1}$ & 12,000 \\
Soil pH & Unitless & 5.49 \\
Soil organic matter & $\% \mathrm{C}$ & 11.69 \\
Precipitation & $\mathrm{m} \cdot \mathrm{year}^{-1}$ & 0.9 \\
Infiltration factor & Unitless & 0.44 \\
Soil bulk density & $\mathrm{kg} \cdot \mathrm{m}^{-3}$ & 1,300 \\
Depth plough layer & $\mathrm{m}$ & 0.2 \\
Time & year & 100
\end{tabular}

Data references in Franco et al. (2006) 
Table 5 Limit values of heavy metals content in compost according to Legislation and its correspondent $\mathrm{HQ}$ and $\mathrm{HI}$

\begin{tabular}{|c|c|c|c|c|c|c|c|}
\hline \multirow[t]{2}{*}{ Source } & \multirow[t]{2}{*}{ Country } & \multicolumn{5}{|c|}{ HQ (Heavy metal content (mg.kg $\left.{ }^{-1}\right)$} & \multirow[t]{2}{*}{$\mathrm{HI}$} \\
\hline & & $\mathrm{Cd}$ & $\mathrm{Cu}$ & $\mathrm{Ni}$ & $\mathrm{Pb}$ & $\mathrm{Zn}$ & \\
\hline \multirow{3}{*}{ Spanish Government (2005) } & Spain-class A & $0.011(0.7)$ & $0.029(70)$ & $0.039(25)$ & $0.015(45)$ & $0.138(200)$ & 0.232 \\
\hline & Spain-class B & $0.014(2)$ & $0.059(300)$ & $0.098(90)$ & $0.026(150)$ & $0.236(500)$ & 0.433 \\
\hline & Spain-class C & $0.013(3)$ & $0.047(400)$ & $0.061(100)$ & $0.021(200)$ & $0.236(1,000)$ & 0.378 \\
\hline \multirow{7}{*}{ Cai et al. (2007) } & Netherlands (clean compost) & $0.011(0.7)$ & $0.022(25)$ & - & $0.018(65)$ & $0.091(75)$ & 0.142 \\
\hline & Netherlands & $0.012(1)$ & $0.028(60)$ & - & $0.021(100)$ & $0.138(200)$ & 0.199 \\
\hline & Canada Class A & $0.017(3)$ & $0.034(100)$ & - & $0.026(150)$ & $0.236(500)$ & 0.313 \\
\hline & Poland & $0.022(5)$ & $0.059(300)$ & - & $0.046(350)$ & $0.508(1,500)$ & 0.635 \\
\hline & UK & $0.013(1.5)$ & $0.047(200)$ & - & $0.026(150)$ & $0.205(400)$ & 0.291 \\
\hline & Australia & $0.017(3)$ & $0.047(200)$ & - & $0.031(200)$ & $0.155(250)$ & 0.250 \\
\hline & USA & $0.019(4)$ & $0.059(300)$ & - & $0.026(150)$ & $0.205(400)$ & 0.309 \\
\hline
\end{tabular}

Limit values for heavy metal content are indicated in parentheses

Application rate $<5 \mathrm{tha}^{-1} \mathrm{year}^{-1}$ in agriculture 


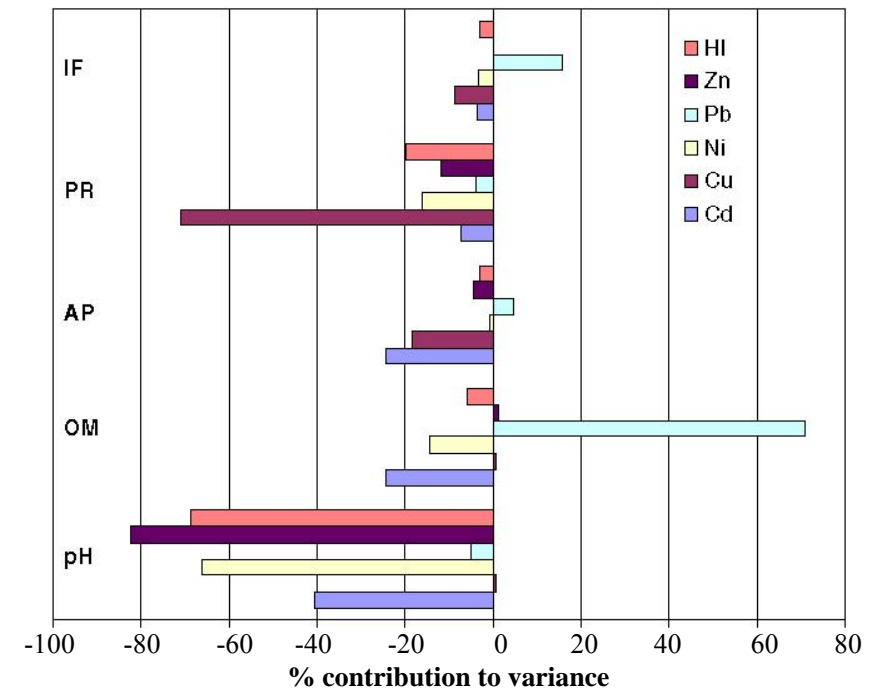

Fig. 2 Influence of soil and climate characteristics $(\mathrm{pH})$, organic matter $(\mathrm{OM})$, average production (AP), precipitation rate (PR), and infiltration factor (IF) on metal hazard quotient (HQ), and hazard index (HI) 